cons:

\begin{tabular}{|c|c|c|}
\hline ENGINEERING CHANGE NOTICE & Page 1 of 2 & $\begin{array}{l}\text { 1. ECN } 629407 \\
\text { Proj. }\end{array}$ \\
\hline
\end{tabular}

\begin{tabular}{|c|c|c|c|c|c|c|}
\hline \multirow{3}{*}{$\begin{array}{l}\text { 2. ECN Category } \\
\text { (mark one) } \\
\text { Supplemental } \\
\text { Direct Revision } \\
\text { Change ECN } \\
\text { Iemporary } \\
\text { Standby } \\
\text { Supersedure } \\
\text { Cancel/Void }\end{array}$} & \multirow{3}{*}{ 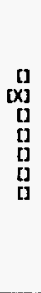 } & \multicolumn{2}{|c|}{$\begin{array}{l}\text { 3. Originator's Name, Organization, MSIW, } \\
\text { and Telephone No. } \\
\text { F. D. Fisher, 15F00, T5-12, } \\
\text { 373-3721 }\end{array}$} & \multicolumn{2}{|c|}{$\begin{array}{l}\text { 3a. Usa Required? } \\
{[X] \text { Yes [] no }}\end{array}$} & $\begin{array}{l}\text { 4. Date } \\
\text { July 10, } 1996\end{array}$ \\
\hline & & \multicolumn{2}{|c|}{$\begin{array}{l}\text { 5. Project Title/No./Hork Order No. } \\
\text { Vertical Direct Denitration } \\
\text { Calciner / K } 6137\end{array}$} & \multicolumn{2}{|c|}{$\begin{array}{l}\text { 6. Bldg./Sys./Fac. No. } \\
234-5 Z \text { / 200-W }\end{array}$} & $\begin{array}{l}\text { 7. Approval Designator } \\
\mathrm{S}\end{array}$ \\
\hline & & \multicolumn{2}{|c|}{$\begin{array}{l}\text { 8. Document Murbers Changed by this ECM } \\
\text { (includes sheet no. and rev.) } \\
\text { WHC-SD-CP-TP-088, Rev. } 4\end{array}$} & \multicolumn{2}{|c|}{$\begin{array}{l}\text { 9. Related ECK No(s). } \\
\text { N/A }\end{array}$} & $\begin{array}{c}\text { 10. Related PO No. } \\
\text { N/A }\end{array}$ \\
\hline \multirow{2}{*}{\multicolumn{2}{|c|}{$\begin{array}{l}\text { 11a. Modification Work } \\
\text { [] Yes (fill out Blk. } \\
11 \mathrm{~b} \text { ) } \\
\text { [X] No (KA Blks. 11b, } \\
11 c_{\text {, }} \text { i1d) }\end{array}$}} & \multirow[t]{2}{*}{$\begin{array}{l}\text { 11b. Work Package } \\
\text { No. } \\
\text { N/A }\end{array}$} & \multirow{2}{*}{\multicolumn{2}{|c|}{$\begin{array}{l}\text { 11c. Modif ication Hork Complete } \\
\qquad \text { N/A }\end{array}$}} & \multicolumn{2}{|c|}{$\begin{array}{l}\text { 11d. Restored to Original Condi- } \\
\text { tion (Tenp. or standby ECM only) } \\
\text { N/A }\end{array}$} \\
\hline & & & & & Cog. En & ineer s \\
\hline
\end{tabular}

12. Description of Change

Replace WHC-SD-CP-TP-088, Rev. 4 with attached copy of WHC-SD-CP-TP-088, Rev. 5.

USQ Evaluation of test plan is PFP-95-021.

\begin{tabular}{|llllllll}
\hline 13a. Justification (mark one) & & & & \\
Criteria Change [] & Design Improvement & {$[X]$} & Environantal & {[]} & Facility Deactivation [] \\
As-Found & {[]} & Facilitate Const & {[]} & Const. Error/Omission & {[]} & Design Error/Omission []
\end{tabular}

13b. Justification Details

Test plan was revised to include purgerator addition.

14. Distribution (include neme, MSIN, and no. of copies)

See Distribution Sheet

A-7900-013-2 (11/94) GEF095 


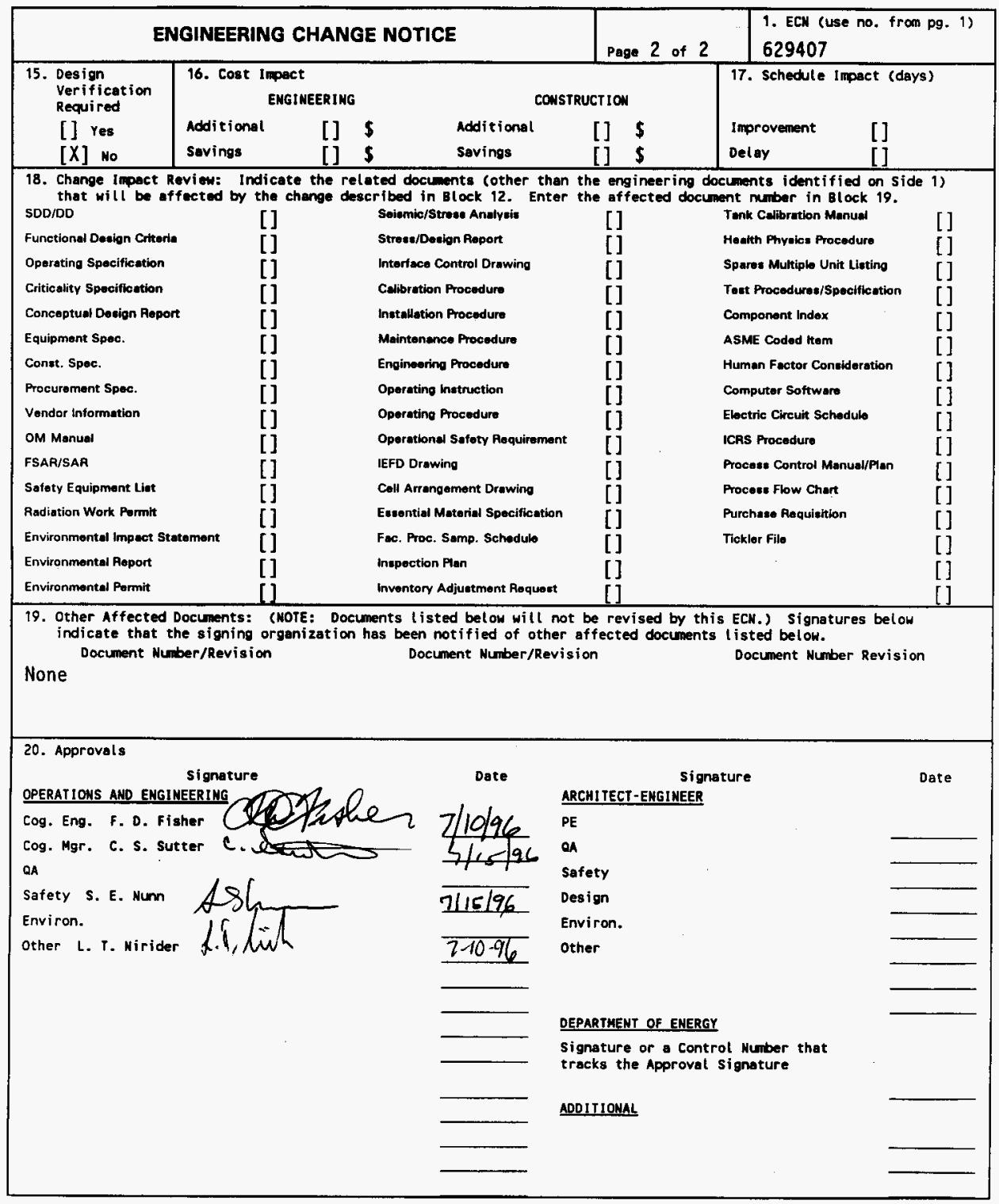




\title{
Test Plan for Radioactive Testing of a Vertical Direct Denitration Calciner
}

\author{
F. D. Fisher
}

Westinghouse Hanford Company, Richland, WA 99352

U.S. Department of Energy Contract DE-AC06-87RL10930

$\begin{array}{lll}\text { EDT/ECN: } & 629407 & \text { UC: } 2050 \\ \text { Org Code: } & 15 F 00 & \text { Charge Code: K6137 } \\ \text { B\&R Code: } & \text { EW7003000 } & \text { Total Pages: } 2022\end{array}$

Key Words: Test Plan, Direct Denitration, Vertical Calciner, Pu-Bearing Liquors

Abstract: A vertical calciner will be used to demonstrate the direct denitration process for converting plutonium-bearing liquors to stable plutonium rich solids. The calciner and some of its associated equipment were previously tested with non-radioactive chemicals to demonstrate operability.

TRADEMARK DISCLAIMER. Reference herein to any specific comercial procuct, process, or service by trade name, trademark, manufacturer, or otherwise, does not necessarily constitute or inply its endorsement, recomendation, or favoring by the United states Government or any agency thereof or its contractors or subcontractors.

Printed in the United States of Anerice. To obtain copies of this document, contact: UHC/BCS Document Control Services, P.O. Box 1970, Mailstop H6-08, Richland WA 99352, Phone (509) 372-2420; Fax (509) 376-4989.
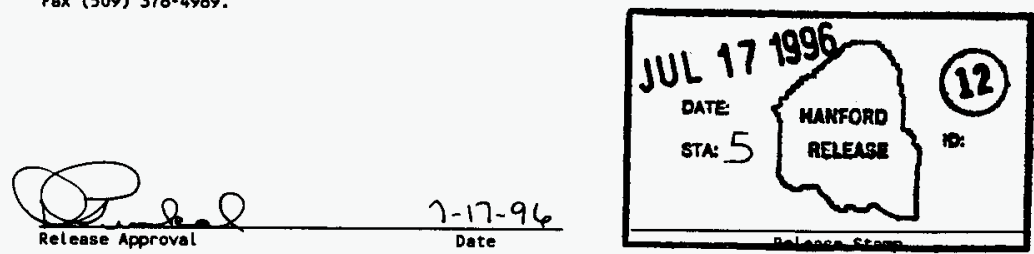

Approved for Public Release 


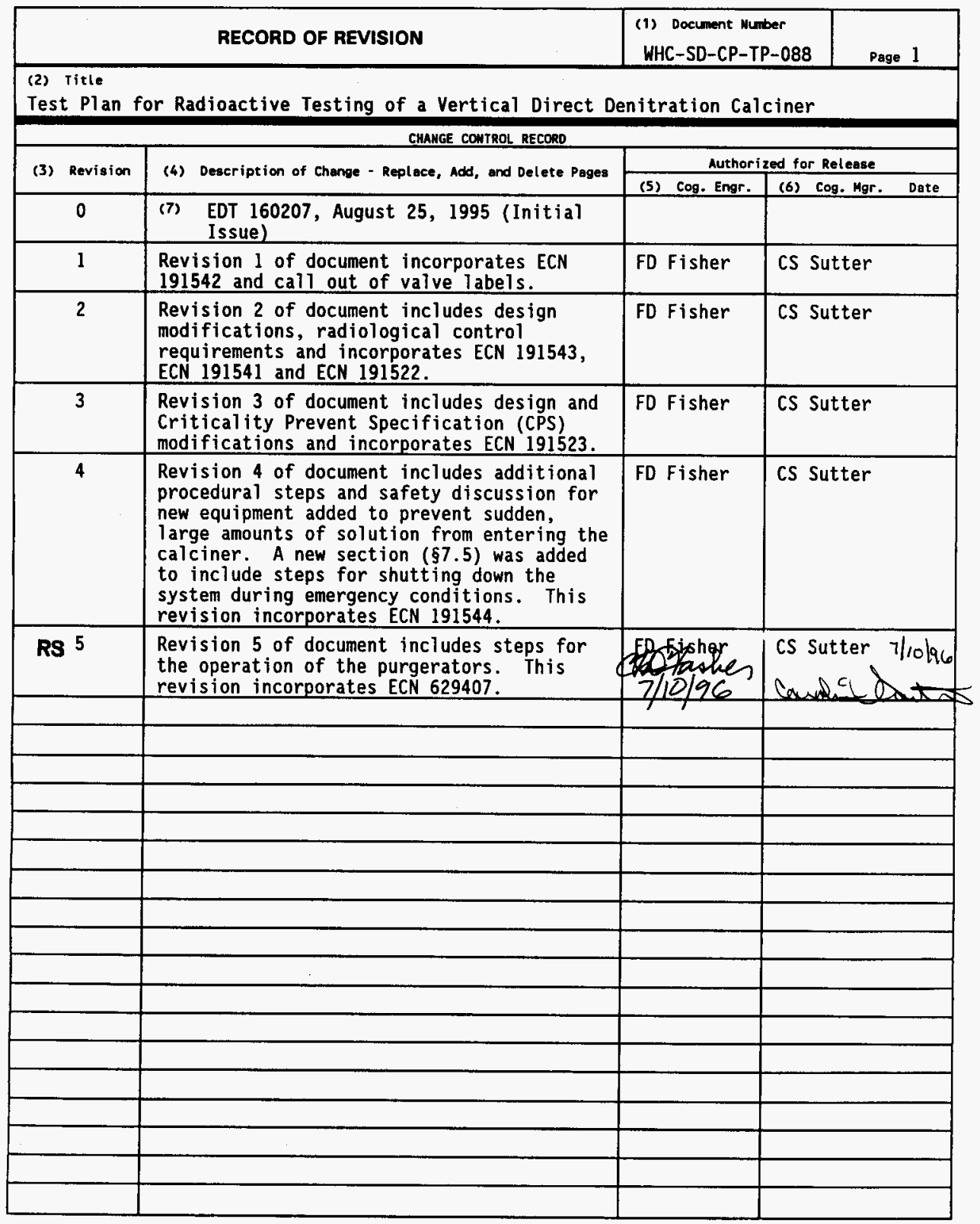




\section{TEST PLAN FOR RADIOACTIVE TESTING OF A VERTICAL DIRECT DENITRATION CALCINER}

\subsection{INTRODUCTION}

Plutonium-bearing liquors containing plutonium and nitric acid and, possibly, uranium and thorium and hydrochloric, sulfuric, phosphoric and hydrofluoric acids and minor amounts of other substances will be used for development and demonstration of a vertical calciner direct denitration process for conversion of those to stable, storable $\mathrm{PuO}_{2}$-rich solids. Some of those liquors are quite dilute and very impure and may first be subjected to various processes for beneficiation and concentration before direct denitration conversion to $\mathrm{PuO}_{2}$-rich solids suitable for long-term vault storage. Untreated scrap liquors containing some amounts of chloride and, possibly, fluoride, sulfate, phosphate, sodium and/or potassium may also be tested for suitability of direct denitration for conversion directly to $\mathrm{PuO}_{2}$-rich solids.

In the vertical calciner direct denitration process to be examined, small additions of liquid feed are metered into a continuously heated and stirred bed of previously generated product solids. The liquid feed is rapidly evaporated, then, more slowly, undergoes drying and denitration and final heat treatment to stable $\mathrm{PuO}_{2}$. The $\mathrm{PuO}_{2}$ product may contain some residual sulfate and/or phosphatederived impurities, but will be substantially free of chloride, fluoride, and other volatile acid impurities. Off-gas condensates are expected to be non-TRU. The process is known to work with plutonium, thorium, uranium, and mixtures of those elements in concentrations ranging from 15 to $500 \mathrm{~g} / \mathrm{L}$. That range may be extended down to ca. $5 \mathrm{~g} / \mathrm{L}$. Schematic diagrams of the vertical calciner and a typical direct denitration flowsheet are Figures 1 and 2.

Problems include materials of construction resistant to abrasion and to $\mathrm{HCl}$ and $\mathrm{HF}$ at $500^{\circ}-1000^{\circ} \mathrm{C}$. Since there is no continuous liquid phase, corrosion is limited to vapor phase attack. Ordinary stainless steel may be adequate for the short term although it would exhibit some oxide scaling on the hotter portions of the calciner. A somewhat higher alloy will be more resistant to oxide scaling. The abrasion problem is not extremely severe and since shaft seals submerged in the powder bed are avoided by design, austenitic alloy construction will be adequate. Hard facing of impellers is not believed to be necessary. Suitable bearings for the impeller shaft present formidable materials problems: graphite is in place now and is expected to wear and, in the case of the lower bearing, to experience some oxidation. Frequent inspection and occasional replacement may be required.

The process is not particularly energy efficient for very dilute feeds and cannot handle feeds high in sodium and potassium or other constituents that form nitrates that are molten and refractory at $\leq 1000^{\circ} \mathrm{C}$ such as acid solutions which have been neutralized with $\mathrm{NaOH}$ or $\mathrm{KOH}$. Organic impurities are largely consumed and only partly report to the offgas.

A vertical calciner has been built and will be used along with associated ancillary equipment in Glovebox 188-1 to demonstrate direct denitration processing of various plutonium solutions to stable, storable $\mathrm{PuO}_{2}$-rich solids. Prior to that, it was temporarily installed in Hood 202-1 and operated "cold," i.e., with non-radioactive stand-in materials, to demonstrate adequate performance of the calciner and most of its associated ancillary equipment items and systems. 
WHC-SD-CP-TP-088 Rev. 5

Figure 1. Schematic Diagram of Vertical Calciner

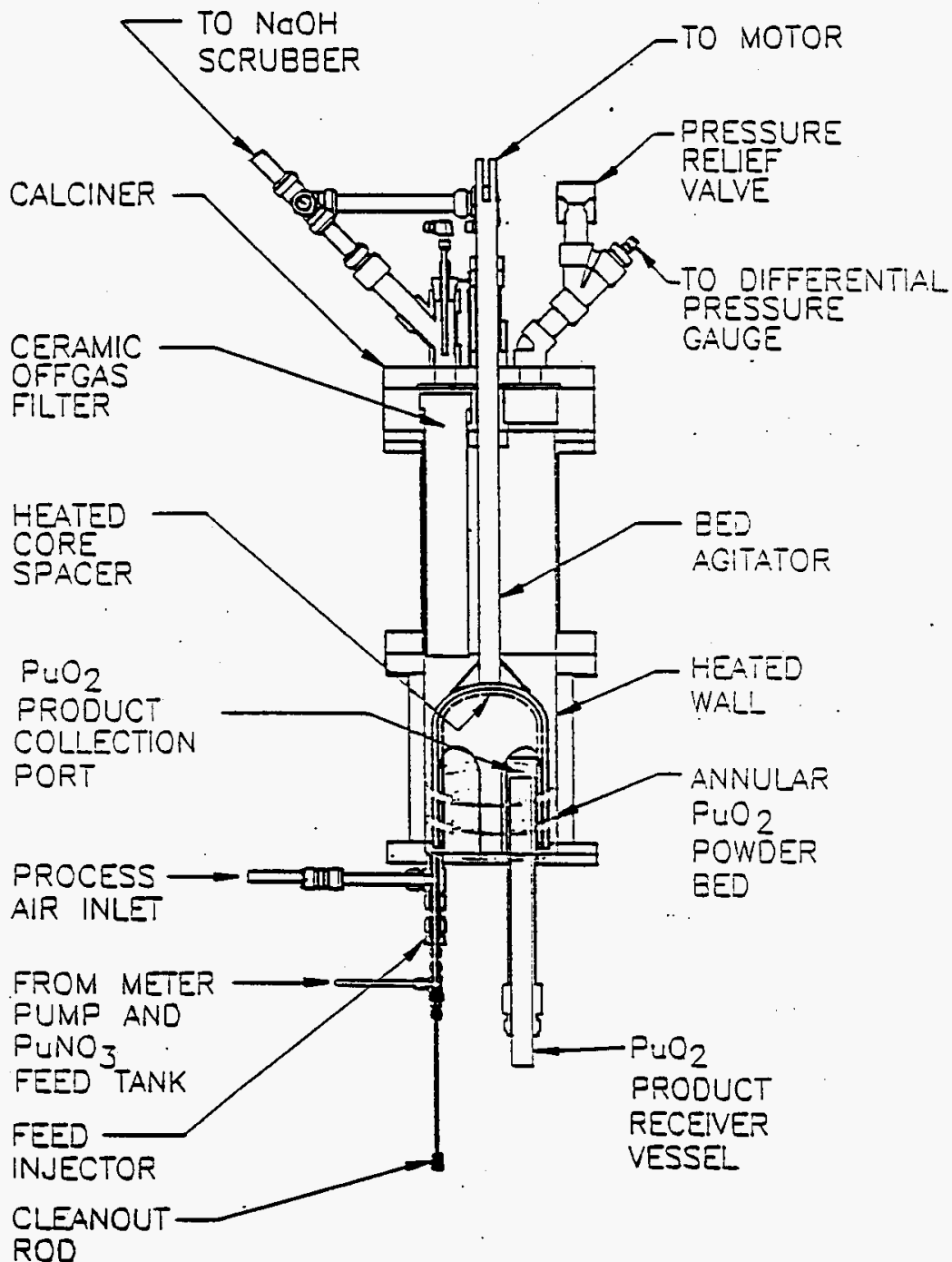




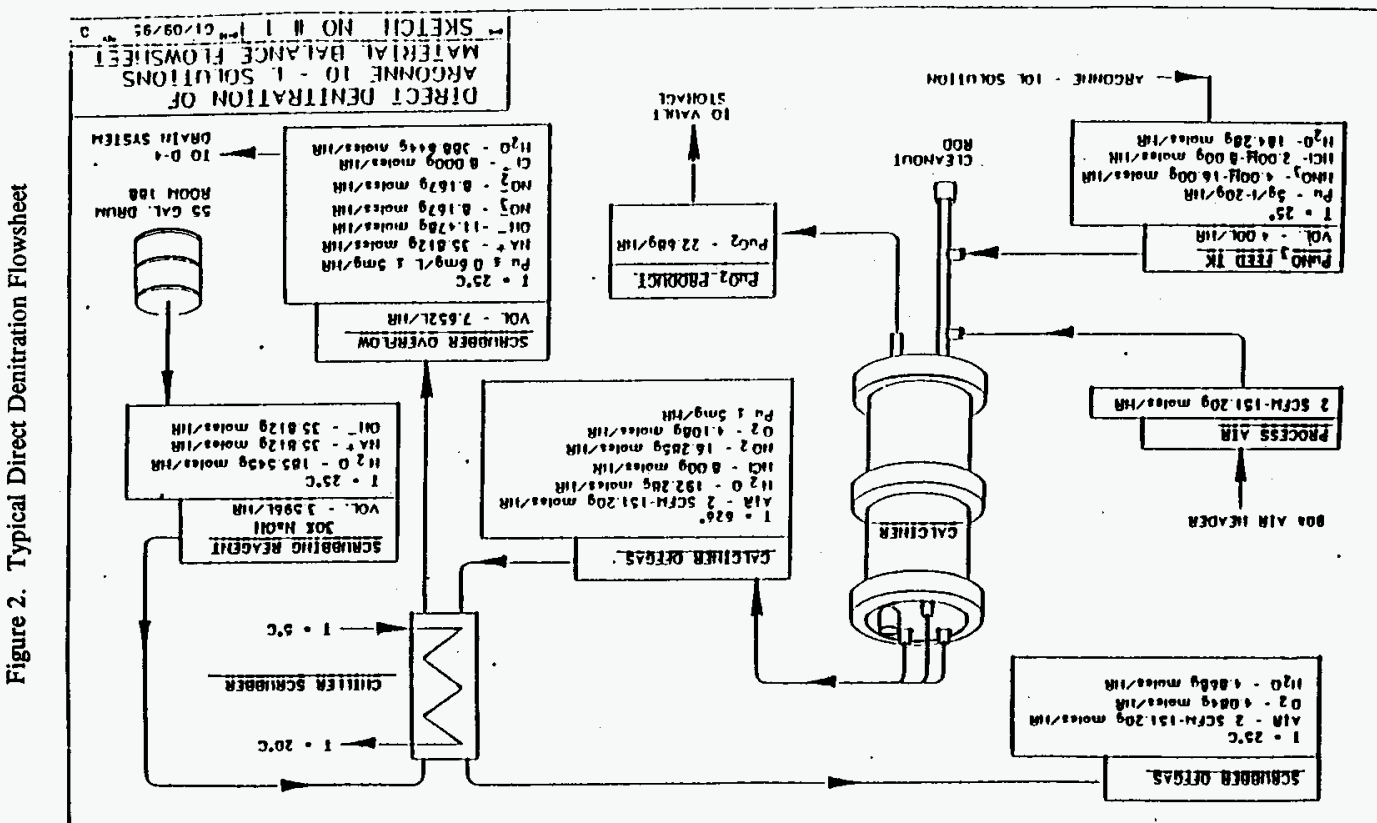




\subsection{OBJECTIVE}

1. To demonstrate satisfactory direct denitration conversion of plutonium bearing solutions to stable solids in a vertical calciner and ancillaries system.

2. To demonstrate the adequacy of performance of the crucial components of a vertical calciner and ancillaries system for direct denitration processing of Pu bearing solutions and to determine deficiencies for possible remediation.

\subsection{SCOPE}

A production-scale vertical calciner and its ancillary equipment will be operated by the Plutonium Process Support Laboratories for several hundred hours with Pu bearing solutions in Glovebox 188-1. The primary source of calciner feed was to have been dilute Pu scrap solutions from ANL but those have been processed by other means. About $400 \mathrm{~g}$ Pu of those purified by anion exchange or EIChrom were converted to $\mathrm{PuO}_{2}$ in the vertical calciner. Further testing will be with other plant solutions.

\subsection{DESCRIPTION OF TEST}

\subsection{Test Items}

The primary test item is the vertical calciner, which is built from high chromium, high nickel Type $310 S$ stainless steel and field insulated. The calciner has an annular design with a 6 inch sch.10 pipe outer shell and an inner shell of 4 inch pipe. The top of the inner shell is a dome shaped pipe cap. Solids inside the calciner are mixed and moved by a 4-tine agitator that fits inside the annulus, covers the dome, and extends out the top center of the apparatus. A chain drive connects the top of the agitator shaft to an offset drive motor. The calciner outer chamber extends above the dome and contains 3 blow back filter elements and a pressure relief device. The agitator shaft is supported in the top plates by two graphite or other bushings and a stuffing box gland. See Figure 1.

Crucial supporting equipment used with the calciner includes an offgas scrubber chiller, feed tank and metering pump, scrub solution tank and metering pump, phase separators, and a vacuum trap. All these items and the calciner are installed in Glovebox 188-1. The scrubber chiller is kept at a constant temperature by a recirculating water chiller located outside the glovebox. See Figure 2 . The calciner control panel is also located outside the glovebox.

Also used will be mounting supports; wiring and instrument lines; interconnecting piping and service lines; and vacuum and compressed air utilities. Electrical services will be via a load center tapped into existing 480-volt service.

Drawing numbers for the crucial equipment pieces and installation are given in Table 1.

The test items also include an about 4 inch deep starter bed of plutonium dioxide in the vertical calciner and a feed stream of plutonium nitrate in nitric acid solution. Additional chemicals may also be present in the feed, notably hydrochloric acid. Plutonium nitrate solution undergoes evaporation and thermal decomposition in the heated stirred bed vertical calciner largely according to: 
TABLE 1

PRIMARY EQUIPMENT DRAWINGS

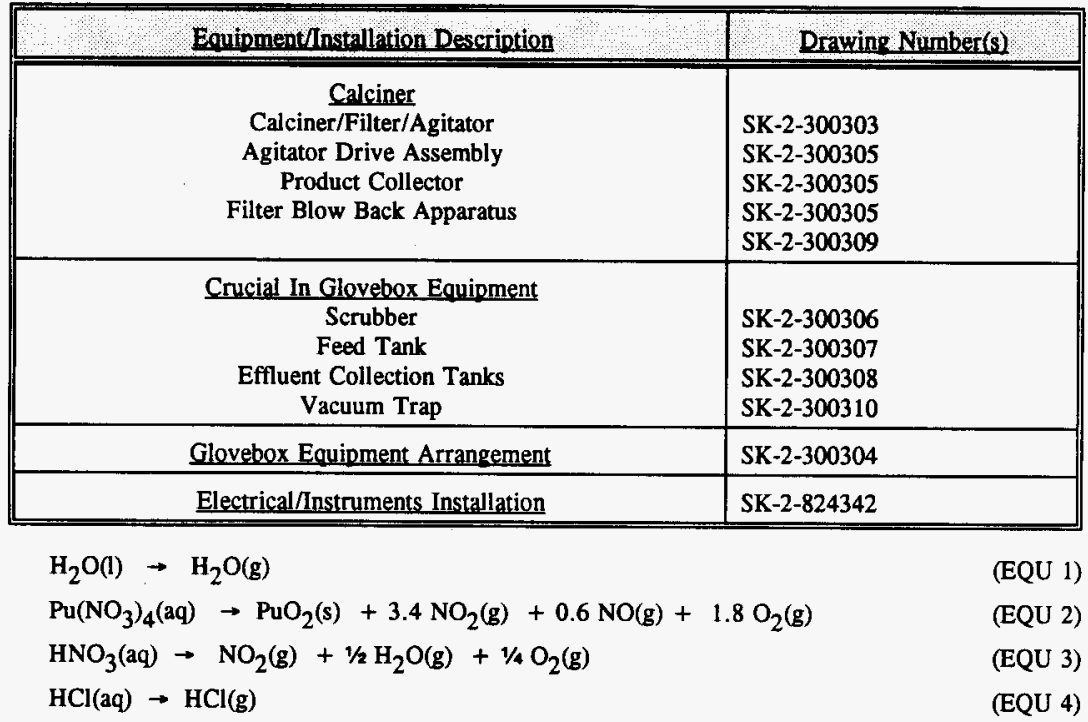

The solid plutonium dioxide formed increases the bed volume, causing solids to overflow to a product receiver vessel below the calciner.

The chiller-scrubber will be used during this test program with recirculating chilled water. The inlet temperature will be about $5^{\circ} \mathrm{C}$ and the outlet temperature is predicted to be about $20^{\circ} \mathrm{C}$. The scrubber will be operated with continuous $30 \%$ sodium hydroxide solution introduction and constant overflow of spent scrub liquor. During the cold testing with tap water as both scrub liquor and cooling water, acid vapors, although less than expected in the hot testing, and their sensible and latent heats were completely removed from the heated offgases.

Other items to be tested include the vacuum regulator, three six point thermocouple recorders, both calciner heaters and their power supplies and controllers.

\subsection{Test Environment}

The testing will be performed in Glovebox 188-1 in Room 188 of the 234-5Z Building, 200-West Area. Control and measurement equipment will be arranged around that glovebox, as appropriate. The glovebox provides confinement of the chemicals in use. The glovebox will breathe room air through three $8 " \times 8 " \times 4^{n}$ inlet filters and will exhaust through three like filters to the E-4 system. 


\subsection{Equipment and Facilities}

Equipment, other than that being tested, includes normal glovebox supporting equipment, an electronic balance, canning supplies and machines, and 4 liter or smaller bottles of plutonium nitrate solution for feed.

Other facilities to be used include Room 190 for vault storage of product and the building radioactive drain system for spent scrubber-chiller liquors.

\subsection{Data}

Temperatures to be measured and recorded include:

$\diamond \quad$ Calciner exterior wall (2 locations, 1 for control and 1 for high temperature alarm)

$\checkmark \quad$ Calciner dome

$\diamond \quad$ Calciner base plate

$\checkmark \quad$ Filter chamber exterior (2 locations)

$\diamond \quad$ Tubing exterior of filtered exhaust (2 locations)

$\checkmark \quad$ Glovebox interior (at E-4 filters)

$\checkmark \quad$ Scrubbed exhaust gases

$\diamond \quad$ Scrubber cooling water inlet and outlet

$\checkmark \quad$ Drive motor exterior

Pressures to be periodically measured and recorded are the pressure difference across the blowback filter elements and the vacuum level inside the calciner filter chamber. All pressure recording will be manual.

The only flow rate measured directly is the pressurized air flow into the calciner at the feed port via a rotameter. Times and solution levels inside the feed tank will be used to check the metered feed flow rate. Scrub solution metered flow rates may be checked in the same manner.

Feed volumes and plutonium concentrations will be known before entry into the glovebox. Product weights will be obtained via the electronic balance inside the glovebox. Product plutonium contents will be determined by calorimetric measurements in 2736-ZB. They will be estimated for transfer | purposes prior to those. Records of these amounts will be kept in the laboratory notebook.

\subsection{Criteria/Constraints}

These tests do not require revision to the PFP Facility Safety Analysis Report (FSAR) (Ref. 1). An Unreviewed Safety Question evaluation, number PFP-95-21, of the test plan for radioactive testing of a vertical direct denitration calciner confirmed that the test operations are within the scope of the FSAR.

\subsection{EXPECTED RESULTS}

The calciner and its associated ancillaries are expected to function smoothly and adequately and that the design throughput capability of $4 \mathrm{~L} / \mathrm{hr}$ of feed solution will be achieved. The calciner and ancillaries are expected to withstand corrosive attack by the acid mixtures in the feeds through the life of the tests. Products from this calciner are expected to exhibit a Loss on Ignition (LOI) of $<0.5$ weight percent at $950^{\circ} \mathrm{C}$. These results are expected with moderately impure solutions and with 
relatively pure feeds prepared from impure solutions by anion exchange and with PUREX or PRF product solutions.

\subsection{SAFETY}

\subsection{Criticality}

Criticality Safety Evaluation Report (CSER) 95-005 and Criticality Prevention Specification (CPS) CPS-L-114-00050 were written exclusively for these tests. This CPS allows any quantity of plutonium at a density not to exceed $5.5 \mathrm{~g} \mathrm{Pu} / \mathrm{cm}^{3}$ in the calciner in Glovebox 188-1 but with severe restrictions on water and aqueous solution availability. Strict adherence to this CPS and related postings will be maintained. Monthly internal inspections by PPSL personnel and additional inspections by the PFP Criticality Safety Representative (CSR) serve as additional compliance checks.

The equipment arrangement design was studied and approved by the CSR prior to issuance.

Densities of delivered $\mathrm{PuO}_{2}$-rich products and, thus, the density of the material in the stirred bed of the calciner will be periodically measured, recorded, and trended to allow operation to cease before, if ever, densities exceed $5.5 \mathrm{~g} \mathrm{Pu} / \mathrm{cm}^{3}$.

The cooling water system for the scrubber presents another theoretical criticality prevention problem. The loop contains about 20 liters of water, much of which is in a reservoir inside the chiller. The reservoir geometry is not favorable for criticality prevention. A criticality is extremely unlikely in the reservoir for four reasons. First, there would have to be simultaneous leaks in the cooling water coils inside the scrubber and at least one blow back filter element to allow plutonium into the cooling water. Second, the cooling water is pressurized and the scrubber shell is under vacuum; therefore, the cooling water would flow into the contaminated scrub solution until the cooling water loop is nearly empty. Third, the workers would have to fail to notice the darkening green color of the scrub solution as the plutonium concentration increased to levels that would cause concern for criticality in the reservoir. The scrubber operates with a constant overflow to the "geometrically favorable" effluent disengagers; therefore, some plutonium would exit the scrubber to those tanks, limiting the plutonium available to enter the cooling loop. Finally, the workers would have to fail to notice the malfunction in the chiller as water is pumped out of the cooling coil into the scrub solution.

\subsection{Radiological Safety}

All work associated with this project will be performed in accordance with the applicable Radiation Work Permits (RWPs). In addition, the dose rates on the glovebox are measured and posted on the glovebox routinely by Radiological Control Technicians (RCTs). The RCTs also routinely check air samplers and Continuous Air Monitors (CAMs) for proper operation and satisfactory work conditions. An RCT must also be present whenever items are moved into or out of the glovebox.

The recirculating cooling water between the chiller and the scrubber-chiller could leak from the tubing. The volume of water in the closed cooling loop is finite and fairly small. The cooling water is theoretically sealed from contamination sources; however, leaks from the contaminated scrub solution into the cooling water are possible. The scrub solution should not be extensively contaminated, though, unless at least one blow back filter element also is breached. Consequently, any leaks should be not only small in volume, but also low in contamination. Additionally, the chiller, scrubber, and connecting tubing are all completely within posted Contamination Areas. 
WHC-SD-CP-TP-088 Rev. 5

Work involving the use of pressurized air inside a glovebox presents the theoretical possibility of pressurizing the glovebox. Glovebox 188-1 was analyzed for potential pressurization previously with air supplied to the glovebox at 15 psig (Ref. 6); pressurization was determined not to be possible. Additional calculations have since been made for air at 40 psig with the same conclusion. At 40 psig, the single air pipe entering the glovebox could deliver only $29.8 \mathrm{scfm}$ and that flow rate of air would be exhausted at a glovebox pressure of only 0.21 inch of water with the glovebox exhaust sealed completely. If both pressure regulators in the air supply line failed simultaneously and made $90 \mathrm{psig}$ air available, the maximum pressure inside the glovebox would still be under 2 inches of water, which is well within the normal operating range for the glovebox inlet HEPA filters. Since these analyses were performed, the inlet air filters have been tripled, thus, further reducing the potential for glovebox pressurization.

Air is introduced into an external mix two-fluid nozzle in the base plate of the vertical calciner. The second fluid is plutonium nitrate solutions. In normal operation the plutonium nitrate solutions are pumped into a central channel in the nozzle assembly and the air enters a concentric outer channel and exhausts at the central channel opening through annular slits. The high velocity air atomizes the exiting plutonium nitrate solution and mixes the aerosolized plutonium nitrate with hot $\mathrm{PuO}_{2}$ powder in the bed above the nozzle where the plutonium nitrate droplets are evaporated, dried, and calcined to $\mathrm{PuO}_{2}$. It is unlikely that nozzle could crust over with dried solid accretions and result in plutonium nitrate solutions being injected into the air channel by the up to 55 psig pressure of the plutonium nitrate feed pump overriding the $65 \mathrm{psig}$ normal atomizing air pressure, or none at all if the compressor should fail. The nozzle is in the calciner bottom plate and is closely wiped by the impeller tines such that an accretion over the nozzle is completely wiped off or made very thin and fractured four times a second by the rotating tines of the vertical impeller. If the impeller is off, so is the feed pump. Nonetheless, a pressure switch in the glovebox air supply header will turn off the feed pump if the air pressure drops below about $60 \mathrm{psig}$, thus actively precluding gross amounts of plutonium bearing liquids being injected into the compressed air supply header. In addition, a bubble-tight check valve is installed in the air line near the feed nozzle.

\subsection{Industrial Safety}

This testing involves high-temperature, electrically heated chemical processing equipment. The thermally hot equipment is extensively insulated and warm surfaces are difficult to reach. The highest exterior temperature recorded during non-radioactive operation was $92^{\circ} \mathrm{C}$ on the agitator shaft where it extends out from the calciner, which is an extremely difficult location to reach inside the glovebox. Temperature-resistant $\operatorname{Kevlar}^{1}$ Hot Mill gloves rated at $450^{\circ} \mathrm{F}$ are available and will be worn if reaching near the warm surfaces is required. Maintenance work will be performed after the calciner has had ample time to cool, if at all possible.

The calciner and scrubber are tall, heavy pieces of equipment and require supports to maintain their upright orientation. The needed supports are provided and are adequate to prevent the equipment from tipping. A hoist is provided in the glovebox to assist with maintenance activities, when needed.

The only exposed rotating part is the top of the agitator shaft, which is difficult and unnecessary to reach during normal operation. The exposed portion contains no sharp or protruding edges. Other pieces of moving or rotating equipment, most notably the agitator drive system, are shielded from workers by guards and/or are difficult to reach during normal operation. The provisions of the WHC

\footnotetext{
${ }^{1}$ Kevlar is a registered trademark of E. I. duPont de Nemours and Co., Inc., Wilmington, DE.
} 
Industrial Safety Manual will be used to maintain safety during maintenance involving rotating or moving parts. A Job Hazards Analysis is attached to this Test Plan (See Attachment 1).

\subsection{Electrical Safety}

All equipment is installed according to designs approved by the appropriate safety organizations. Electrical connections are tested for proper installation prior to starting these tests. Bare electrical connections will not be accessible to casual contact. The provisions of the WHC Industrial Safety Manual will be used to maintain safety during maintenance involving electrical parts. A Job Hazards Analysis is attached to this Test Plan (See Attachment 1).

\subsection{Chemical Safety}

Most chemical operations occur inside the glovebox, which shields workers from chemical hazards. Protective clothing required by the RWPs and the glovebox ventilation system serve as additional barriers to chemical exposure. Chemical safety outside the glovebox is assured by rigid adherence to the PPSL Chemical Hygiene Plan (Ref. 7). The MSDSs for all non-radioactive chemicals are available in Corridor 8.

Due to the high operating temperature reached prior to feed commencement, any sudden "large" amounts of feed entering the calciner will vaporize rapidly, possibly overwhelming the off-gas system's ability to remove the vapors as they form. The introduction of a large amount of feed suddenly is most likely to occur when clearing a solid plug in the feed nozzle if the plug is not noticed quickly. This possibility is minimized by the installation of a check valve before the pressurized air enters the annulus around the solution feed line. In addition, a rotameter in the pressurized air line just before the check valve allows easier detection of pluggage. A cessation of flow through the rotameter indicates that the feed nozzle may be plugged. Also, any detection of solution flowing backward through the rotameter indicates that the check valve is not working and solution is accumulating in the pressurized air system. The pressurized air might drive the accumulated solution volume into the calciner very suddenly once the plug is cleared; therefore, steps are included in the Procedure section to minimize this possibility. First, plug removal requires that the feed pump be shut off and that the pressurized air system be shut off and vented. This step eliminates the motive force for driving solution into the calciner. Second, if any significant accumulation of feed solution is suspected in the pressurized air system, the calciner must be shut down and the feed and/or air lines disassembled to remove the accumulated solution.

Overpressurization of the calciner from chemical reactions or excessive feed flow is minimized by a pressure relief device. The device is a 3/4-inch hole at the top of the calciner with a cap held on by gravity and beveled edges. The cap will be lifted upward to relieve pressure starting at $1.3 \mathrm{psig}$. Experience during non-radioactive testing has confirmed that the pressure relief device works as intended.

That relief valve can vent all the gases generated in or introduced into the calciner at any realistic rate at well below the pressure required to rupture the calciner, i.e., about $300 \mathrm{psig}$, even with the offgas system sealed off. The feed pump will not inject feed at pressures above 55 psig. The atomizing air and blowback air are normally $60-65$ psig, but the ultimate pressure available to both of those is only 90 psig. A steam surge from siphoning back of scrub liquor into a hot calciner would be limited by pressurization terminating the siphoning after only a small amount of scrub liquor was introduced to the hot calciner and the pressure would be safely vented back to the scrubber-chiller and through the relief valve. 
Four methods are used to prevent organics from entering the calciner, where they might combust. First, the download procedure for removing the solutions from their original containers requires a visual check for a second liquid phase. Second, sample analyses by the PFP Analytical Laboratory confirm the lack of organics in the feed samples. Third, most of the calciner feed solution has been processed through either an anion exchange column or an extraction chromatography column, which would separate organics from the plutonium. Finally, the feed tank in the calciner glovebox is glass, allowing staff to notice any organic phase in the feed. The calciner can safely accept small to moderate amounts of organics. Those are promptly combusted upon introduction and, thus, cannot accumulate into hazardous quantities.

\subsection{TEST PROCEDURE}

\subsection{Operability Check}

\section{NOTE}

This section may be interrupted, as needed, to obtain craft support for repairs, adjustments, or corrections to equipment and installation. Rigorous compliance with the PFP Lock and Tag program is required for all maintenance activities.

1. Turn on power to the control panel. Ensure that all lights, controls, and recorders have power and are operating properly for this stage of operation.

2. Program the temperature controllers and recorders, as needed, if not still programmed correctly from prior operations. Programming instructions are in the operating manual (Ref. 2 and 3 ).

3. Open the valve for the building vacuum system and adjust regulator to 44 inches $\mathrm{H}_{2} \mathrm{O}$ or other as directed in laboratory notebook in the calciner. Close vacuum system valve after adjustments are made.

4. Add the starter bed of $\mathrm{PuO}_{2}$ to the calciner, as follows:
a. Start the calciner agitator. Building vacuum may also be used, if available. Product receiver must be in place.
b. Remove the top half of the pressure relief device to uncover the vent hole.
c. Insert a funnel into the pressure relief hole. shake the funnel gently to assist the powder in flowing down into the calciner chamber. Use a brush or scoopula, if needed, to assist in removing the powder from the original container(s).
d. Carefully pour the $\mathrm{PuO}_{2}$ from its container(s) into the calciner through the funnel. Tap or
e. When finished loading, brush or shake as much powder as possible from the funnel into the calciner.
f. Remove the funnel and place the top half of the pressure relief device back in position.
g. Turn off the agitator and the vacuum.

5. Add ca. $0.5 \mathrm{~L}$ water to the feed tank. Temporarily connect feed pump to utility outlet. Prime the feed pump per the operating manual's instructions (Ref. 4) with the pump outlet line disconnected from the calciner. Shut off the pump when the first drop of liquid exits the outlet line. Reconnect the feed line to the calciner. Reconnect the feed pump to the panel controlled power supply. 


\section{NOTE}

The pump stroke frequency may be changed at any time, but the pump stroke length may be changed only when the pump is running.

6. Temporarily connect the $30 \% \mathrm{NaOH}$ scrubber-chiller feed pump to the utility outlet and a water supply.

7. Prime the $30 \% \mathrm{NaOH}$ scrubber-chiller-feed pump with water per the operating manual's instructions at $100 \%$ flow and fill the scrubber-chiller about $2 / 3$ full of water. Visually check lines and joints for leaks. Insert foot valve into $\mathrm{NaOH}$ drum. Reconnect pump to panel controlled power supply.

8. Fill the closed cooling loop between the chiller and scrubber with water. Turn on the chiller per the operating manual's instructions (Ref. 5) to begin circulating the cooling water and confirm that the chiller is operating properly. Visually check lines and joints for leaks. Shut off the chiller after confirming acceptable operation.

9. Turn on the agitator drive motor and adjust the rotational speed, as desired. Nominally 60 RPM. Record the rotational speed and necessary dial setting in the laboratory notebook for later reference. Additional speeds and their dial settings may also be determined and recorded, if desired. Turn off the agitator drive system.

10. Open the valve for the compressed air supply and adjust the regulators, if necessary, for the desired line pressure, i.e., 65 psig to glovebox and blow-back system and 65 psig to atomizing nozzle. Close the compressed air valve after adjustment is made.

11. Turn on the blow-back timing system and adjust, as needed. Nominally 0.5 second pulses every 90 seconds. Turn system off after adjustments are made.

12. Confirm that the calciner heater controller is still programmed properly from prior tests. Temperature set point is $1000^{\circ} \mathrm{C}$. Ramp up rate is $8^{\circ} \mathrm{C}$ per minute. Ramp down rate is $5^{\circ} \mathrm{C}$ per minute. Overtemp alarm at $1150^{\circ} \mathrm{C}$. Others as directed by logbook direction. Turn on power to the heaters long enough to confirm that (a) the calciner is heating at the proper rate and (b) the increasing temperatures are being recorded on the temperature indicators and recorders. Shut off the controller program by depressing the Up Arrow and Down Arrow simultaneously on the controller face.

13. Shut off power to the control panel, if desired or necessary.

\subsection{Start-Up}

\section{NOTE}

Step 6 may be performed at any time prior to the stated temperature of $400^{\circ} \mathrm{C}$, if necessary due to room access limitations.

1. Introduce plutonium nitrate feed, as required, into the glovebox per ZP-100-002, "Seal In- PPSL Gloveboxes" or ZP-100-003, "Use PPSL Airlocks", and thence, into the feed tank. Enter on inventory posting sheet and into notebook. 
2. Ensure that heat controller and temperature alarm thermocouples are in their proper positions. Turn on power to the calciner heaters. Check programming for control temperature set point to be $1000^{\circ} \mathrm{C}$, ramp up at $8^{\circ} \mathrm{C} / \mathrm{min}$, dwell for 60 minutes, ramp down at $5^{\circ} \mathrm{C} / \mathrm{min}$, overtemp alarm at $1150^{\circ} \mathrm{C}$ or others as directed by logbook instruction. Confirm that the calciner is heating at the appropriate rate.

3. Open the valve for the building vacuum system to establish air flow through the calciner and filters.

4. Open the valve for compressed air flow into the calciner. Adjust the rotameter to indicate 30 scth (this indication should correspond to an actual $40 \mathrm{scfh}$ after correction for the estimated pressure inside the rotameter) or other rate as specified by logbook instruction.

5. Open valve in product delivery tube. Set purgerators into the product receiver and the calciner pressure sensing line to 1 SCFH or other as directed.

6. Turn on the agitator drive motor. Adjust its speed to 60 RPM or other as directed by logbook instruction.

7. After the controlling temperature on the calciner outer wall reaches $400^{\circ} \mathrm{C}$, turn on the chiller and begin circulating cooling water through the scrubber.

8. After the controlling thermocouple indicates the desired furnace operating temperature, $1000^{\circ} \mathrm{C}$ or other as directed by logbook instruction, increase the compressed air flow rate at the rotameter to an indicated $45 \mathrm{scfh}$ (estimated actual $60 \mathrm{scfh}$ ) or other as directed by logbook direction.

9. Turn on the filter blow-back system, 65 psig, 0.5 second pulses every ca. 90 seconds, or other as directed by logbook instruction.

10. Turn on the scrub solution pump and begin pumping $30 \% \mathrm{NaOH}$ solution into the scrubber at a rate to equal in hydroxide equivalents the acid in the feed plus enough extra to make the effluent ca. 1.5M in excess hydroxide, as directed by logbook instruction from prior makeup calculations.

11. Turn on the feed pump and begin pumping feed solution into the calciner at $4.0 \mathrm{~L} / \mathrm{hr}$ or other as directed by logbook instruction. Observe the atomizing air rotameter to confirm that air is still flowing properly into the calciner and that feed solution is NOT flowing backward through the rotameter.

12. Confirm that the valve between the calciner and product collection pot is open.

\subsection{Steady-State Operation}

1. Periodically check the solids content of the product collector. 
2. When the collector is nearly full, empty the collector as follows:

\section{CRITICALITY}

Be certain there is an open corner in the triangular plate beneath the collection pot before starting this sequence.

a. Tare weigh a slip lid can. Assign a number to this can; record the can number and tare weight in the laboratory notebook.

b. Turn off the feed and scrub liquor metering pumps and the purgerator on the product receiver.

c. Close the valve between the calciner and product collection pot.

d. Carefully undo the clamps holding the collection pot in place, making certain that the pot does not fall.

e. Very carefully pour the collected powder from the collection pot into the tared slip-lid can. Use brushes, if needed, to minimize dusting.

f. Reattach the collection pot and open the valve between it and the calciner. Reset the purgerator flow.

g. Restart both the feed and scrub liquor metering pumps.

h. Tare weigh a $10 \mathrm{ml}$ plastic graduated cylinder. Introduce 5 to $7 \mathrm{mls}$ of product $\mathrm{PuO}_{2}$ into the cylinder. Tap down. Measure and record volume. Weigh and record. Return sample to slip-lid can.

i. Weigh the loaded slip-lid can. Record the gross weight in the laboratory notebook. Calculate the net weight of powder and record this amount in the notebook. [Note: The gross weight and net weight may be the same if the balance has an automatic tare feature].

j. Tare weigh a numbered sample bottle. Remove ten grams of powder from the slip lid can and transfer it into the sample bottle. Reweigh the sample bottle to obtain the sample weight. Attach the sample bottle cap and set the sample aside for later submission to the PFP Analytical Laboratory for Loss on Ignition analysis.

k. Place the lid on the slip-lid can and seal with tape. Set the can in an open corner of the triangular plate beneath the collection pot.

1. Calculate product $\mathrm{PuO}_{2}$ density. Note and record. The density may not exceed $5.5 \mathrm{~g}$ $\mathrm{Pu} / \mathrm{cm}^{3}$ (i.e. $6.24 \mathrm{~g} / \mathrm{cm}^{3}$ ) tap density. Should the measured tap density exceed 6.24 $\mathrm{g} / \mathrm{cm}^{3}$, stop operation, notify the PFP Criticality Representative. Prepare, get reviews and approvals and implement a recovery plan.

3. Monitor the time remaining in the Dwell portion of the temperature controller program. This indication tells you the number of minutes remaining at steady-state operation. The controller will automatically begin to cool at the programmed ramp-down rate when the Dwell time reaches 0.0 minutes. Depress the Run/Hold button any time during the Dwell step to hold the heaters at steady-state operation for as long as necessary. The Dwell step will resume where it stopped when the Run/Hold button is depressed again.

4. Periodically examine the contents of the scrubber-chiller in the lower annular downcomer and the quiescent chamber beside the gas distributor and/or the scrub liquor effluent receiver tanks for turbidity. Marked turbidity indicates a failed offgas filter. Do not mistake finely dispersed gas bubbles for turbidity. Scrub liquors can be slightly turbid with a grayish material, presumably sodium carbonate. 


\section{CRITICALITY}

The scrubber-chiller and the disengagers are critically safe by geometry for plutonium slurries but ALARA principals make it necessary to limit plutonium contents in liquors going to the waste tanks.

Under no circumstances are gross quantities, i.e., approaching the $400 \mathrm{~g}$ Pu mass limit of the 241$Z$ receiver tanks, to be introduced into the $D-4$ drain system.

If marked turbidity is noticed, shut down feed and scrubber-chiller liquor pumps, atomizing air, both purgerators and blowback air, and offgas vacuum immediately. Turn off heater power subsequently. Prepare, get appropriate reviews, and implement formal recovery procedures.

5. Observe the feed tank volumes and times to confirm the feed flow rate.

\section{CRITICALITY}

Be certain to check all aspects of the CPS posting before introducing additional feed solution into the glovebox.

6. Periodically, add more feed solution to the feed tank per ZP-100-002, "Seal In - PPSL Gloveboxes", or ZP-100-003, "Use PPSL Airlocks", as needed. Note volumes and concentrations. Enter onto inventory posting sheet and into laboratory notebook. Project necessary scrub liquor rate in notebook calculation. Change scrub liquor rate as appropriate.

\section{CRITICALITY}

Do not drain phase disengager if it exhibits marked turbidity. Shut down feed and scrubberchiller liquor, atomizing air, purgerators and blowback air, and offgas vacuum immediately. Turn off heater power subsequently. Prepare, get appropriate reviews, and implement formal recovery procedures.

7. Periodically check the scrub solution disengagers system liquor levels. Make certain that the vacuum trap is operating acceptably. Adjust valving, as needed, to switch between disengagers during operation. Drain the disengager not in use, as needed, per the following instructions:

a. Open the tank vent valve.

b. Drain a sample of the solution from the "full" disengager into a numbered $22 \mathrm{~mL}$ sample bottle.

c. Close the sample cock.

d. Set the sample bottle aside for later submission to the PFP Analytical Laboratory.

e. After receiving sample results and approval of PFP Engineering and PFP Operations, open the valve to the $D-4$ drain and the tank vent valve. 
f. Close the drain valve.

8. Perform frequent checks of the atomizing air rotameter and the feed pump's bypass loop. Confirm that air is flowing properly into the calciner and that solution is not flowing backward through the rotameter. Loss of air flow, liquid flowing through the bypass loop, or backflow of solution through the rotameter indicates probable feed line pluggage that can be cleared as follows:

\section{SAFETY}

If a significant quantity of feed solution is known or suspected to have accumulated in the pressurized air line(s), shut down and contact Maintenance for disassembly of the feed and/or air lines. The steps below are for use only when the loss of air flow is noticed quickly enough to prevent a large amount of feed from entering the calciner rapidly when the plug is cleared.

a. Turn off the agitator.

b. Shut off the feed pump. Relieve the feed pump pressure and allow any feed in the feed and air lines to blow back into the feed tank by pulling the priming knobs on the feed pump outlet assembly. Close these knobs before the feed line is totally empty.

c. Turn off the air supply to the rotameter. In the top level of the glovebox, relieve the pressure in the accumulator tank.

d. Loosen the gland nut at the base of the feed tube assembly to free the clean-out rod.

e. Push the clean-out rod slowly and carefully upward all the way to remove the suspected pluggage. If the rod will not move all the way up, shut down and contact Maintenance for disassembly to correct the problem.

f. Return the clean-out rod to its original position and tighten the gland nut loosened in step d.

g. Turn the pressurized air supply back on. Confirm that air is flowing properly through the rotameter. If air does not flow through rotameter, shut down and contact Maintenance.

h. Turn on the agitator.

i. Turn on the feed pump. If needed, reprime the pump per the operating manual instructions.

\subsection{Shut-Down}

1. After the desired amount of feed has been processed through the calciner, turn off the power to the calciner heaters. The power may be shut off by any one of the methods below:

a. Allow the temperature controller to finish its programmed Dwell portion of the operating program and it automatically begins to cool. 

b. Simultaneously depress both the Up Arrow and Down Arrow on the face of the temperature controller.

c. [Least desirable method] Push in the button-shaped switch that controls power to the heater controller or turn off the master power switch.

2. Reduce the compressed air flow rate to an indicated 30 scth or other flow rate, if so directed by logbook notation. Higher flow rates increase the cooling rate for the calciner, making it more likely to be cooled for maintenance the next day. Lower flow rates (or none) decrease the cooling rate and the conserved heat makes the next day's start-up shorter.

3. Before leaving the calciner unattended, shut off the agitator, scrub solution, compressed air, vacuum, and water chiller. Be sure the compressed air is shut off BEFORE shutting off the vacuum. If desired to leave air flowing through the cooling calciner overnight, the vacuum must also be on if the pressurized air is left on. The master power switch may also be turned off, if desired. Wait about 20 minutes after shutting off the feed pump to allow the bed to stop decomposing and producing $\mathrm{NO}_{\mathrm{x}}$, then remove the cap on the pressure relief device. If fumes exit the relief port, replace the cap and wait longer before leaving the cap off.

\subsection{Emergency Conditions Responses}

\section{Criticality Horn}

Shut off power at the button-shaped Emergency Shutdown switch on the control panel, if passing by the panel. Run from the building immediately per normal criticality horn response.

\section{Continuous Air Monitor}

If not wearing respiratory protection, shut off power at the button-shaped Emergency Shutdown switch on the control panel, if passing by the panel. Leave the room and contact the Radiological Control Technicians (RCT).

If wearing respiratory protection, continue operation unless ordered to leave by the RCT.

\section{Evacuation Siren}

Shut off power at the button-shaped Emergency Shutdown switch on the control panel. Shut off any other powered devices by depressing their red lights on the control panel. Shut off the compressed air supply (first) and the vacuum supply (second). Crack open the cap on the pressure relief device at the calciner top. Evacuate the room and building per normal evacuation siren response.

4. Fire Alarm

Shut off power at the button-shaped Emergency Shutdown switch on the control panel. Shut off any other powered devices by depressing their red lights on the control panel. Shut off the compressed air supply (first) and the vacuum supply (second). Crack open the cap on the pressure relief device at the calciner top. Evacuate the room and building per normal fire alarm response. 


\section{Take Cover Siren}

No response is required. Continue operating normally unless instructed to shut down by management.

\section{Orderly Exit of Zone III}

Shut down normally per Section 7.4. Notify the building Emergency Director that the shutdown and exit will require about half an hour. If directed to leave sooner, use the response for an evacuation siren but without leaving the building.

\section{Fissile Material Movement Bans/Restrictions}

Shut off only the feed pump, unless directed by management or the Criticality Safety Representative (CSR) to shut down completely (via Section 7.4). The CSR has determined that running the agitator does not constitute "movement of fissile material."

8. Lock-Downs

No response is required, unless specifically directed by Patrol or management. If directed to leave, respond as per the evacuation siren instructions but without leaving the building.

\subsection{QUALITY ASSURANCE}

These tests are being performed to the requirements for prototype equipment as detailed in Standard Engineering Practices (WHC-CM-6-1), Practice EP-2.4, "Development Control Requirements". There are no requirements for independent witnessing or review of tests nor are there any specific standards to be met. Equipment will not be calibrated to NIST-traceable accuracy.

\subsection{ORGANIZATION AND FUNCTION RESPONSIBILITIES}

\subsection{Plutonium Process Support Laboratories}

The PPSL staff prepares all test plans and procedures, performs all tests, and documents results from testing. The PPSL Cognizant Engineer also reviews and approves all designs and procurement for equipment and its installation. The PPSL technical staff also prepares formal presentations based on the test results.

\subsection{PFP Design Engineering}

Design Engineering prepares all fabrication and installation designs and relevant bills of material. Design Engineering also reviews and approves this test plan. Documentation and presentation of designs is also performed. Design Engineering also observes the tests, as needed.

\subsection{PFP Process Engineering}

Process Engineering reviews and approves this test plan and results documentation. Process Engineering also observes the tests, as needed. 


\subsection{PFP Maintenance}

Maintenance crafts review designs, fabricate and install the equipment for use, and may observe the tests.

\subsection{PFP Operations}

The PFP Operations organization provides all required utilities and services to the glovebox and laboratory area, primarily ventilation, vacuum, lighting, electrical power, pressurized air, and water.

Transition Operations provides trained operators to assist with loading equipment into the glovebox and associated tasks, such as decontamination. Transition Operations management also reviews and approves this test plan. Transition Operations personnel may observe testing, as desired.

Solid Waste Operations assists with the disposal of all effluents and wastes.

\subsection{Safety}

The PFP CSR reviews and approves equipment designs for criticality safety, assists with the CSER, and writes the CPS and associated posting(s). The CSR also reviews and approves the test plan for criticality safety concerns. The CSR inspects the PPSL area periodically to confirm compliance with all applicable CPS postings. The CSR also observes the tests, as desired.

The PFP Nuclear Safety representative reviews and approves this test plan and periodically performs surveillances to ensure compliance with nuclear safety requirements, including criticality safety. The nuclear safety representative also observes the tests, as desired.

The PFP Industrial Safety Representative reviews and approves this test plan and performs periodic surveillances to ensure compliance with industrial safety rules. The industrial safety representative also observes the tests, as desired.

\subsection{Quality Assurance}

Quality Assurance personnel review and approve designs and this test plan. Test observations may be performed, as desired.

\subsection{PFP Environmental Engineering}

PFP Environmental Engineering reviews records of effluent solutions and assists in their disposal. PFP Environmental Engineering also reviews and approves this test plan. Test observance may be performed, as desired.

\subsection{PFP Security}

The PFP Security Representative reviews and approves the material requirements and associated safeguards for special nuclear material (SNM) protection. Test observance may be performed, as desired. 


\subsection{Department of Energy}

Department of Energy personnel or their representatives review the test plan. Test observation may be performed, as desired.

\section{SCHEDULE}

These tests are to begin upon completion of equipment acquisition and installation. Tests are anticipated to continue until all Argonne scrap solutions in the PFP inventory have been tested. Additional solutions may be tested, as needed, during or after testing of the Argonne solutions. The duration of testing will not be predicted due to the uncertainties in the numbers of solutions to be tested and any required maintenance or design changes.

\subsection{REPORTS}

A final test report will be issued after completion of these tests. It will be issued as a supporting document, external publication, or speech/article in accordance with Standard Engineering Practices (WHC-CM-6-1), Practice EP-1.12, "Supporting Document Requirements." Progress of the testing will also be reported weekly in the PPSL Weekly Report.

\subsection{REFERENCES}

1. Plutonium Finishing Plant Facility Safety Analysis Report (WHC-SD-CP-SAR-021, Rev. 0), Westinghouse Hanford Company, Richland, WA, January, 1991.

2. Eurotherm Corporation, Bulletin $8180 \mathrm{P}-8$, Euotherm 818 Controller/Programmer Operating Instructions, Eurotherm Corporation, Reston, VA.

3. ABB Kent-Taylor, Inc., Bulletin PB PR100-94.2, "Commander ${ }^{\text {M }}$ PR100 Advanced Process Recorder," ABB Kent-Taylor, Inc., Rochester, NY, 1994.

4. LMI Corporation, Liquid Metronics Division, Catalog Section 6.0, "Electronic Metering Pumps: Installation, Maintenance, Troubleshooting," LMI Milton-Roy,Acton, MA, July, 1994.

5. Neslab Instruments, Inc., "CTF-300 Recirculating Chiller, Instruction and Operation Manual," Neslab Instruments, Inc., Newington, NH, September 9, 1994.

6. Compton, J. A., Supporting Document WHC-SD-CP-TA-008, Rev. 0, "Comparison of Deliverable and Exhaustible Pressurized Air Flow Rates in Laboratory Gloveboxes," Westinghouse Hanford Company, Richland, WA, August, 1994.

7. Sant, W. H., WHC-SD-CP-HSP-001, Rev. 3, "Westinghouse Hanford Company Chemical Hygiene Plan," Westinghouse Hanford Company, Richland, WA, May 1995.

\subsection{DATA SHEETS}

Data will be recorded in Controlled Laboratory Notebook, WHC-N-967-1, with recorder traces or any other mechanically produced data stored separately as noted in that notebook. Those data items will be identified on the PPSL RIDS plan as record material. 


\section{SEST KHEALAELE COPY}

WHC-SD-CP-TP-088 Rev. 5

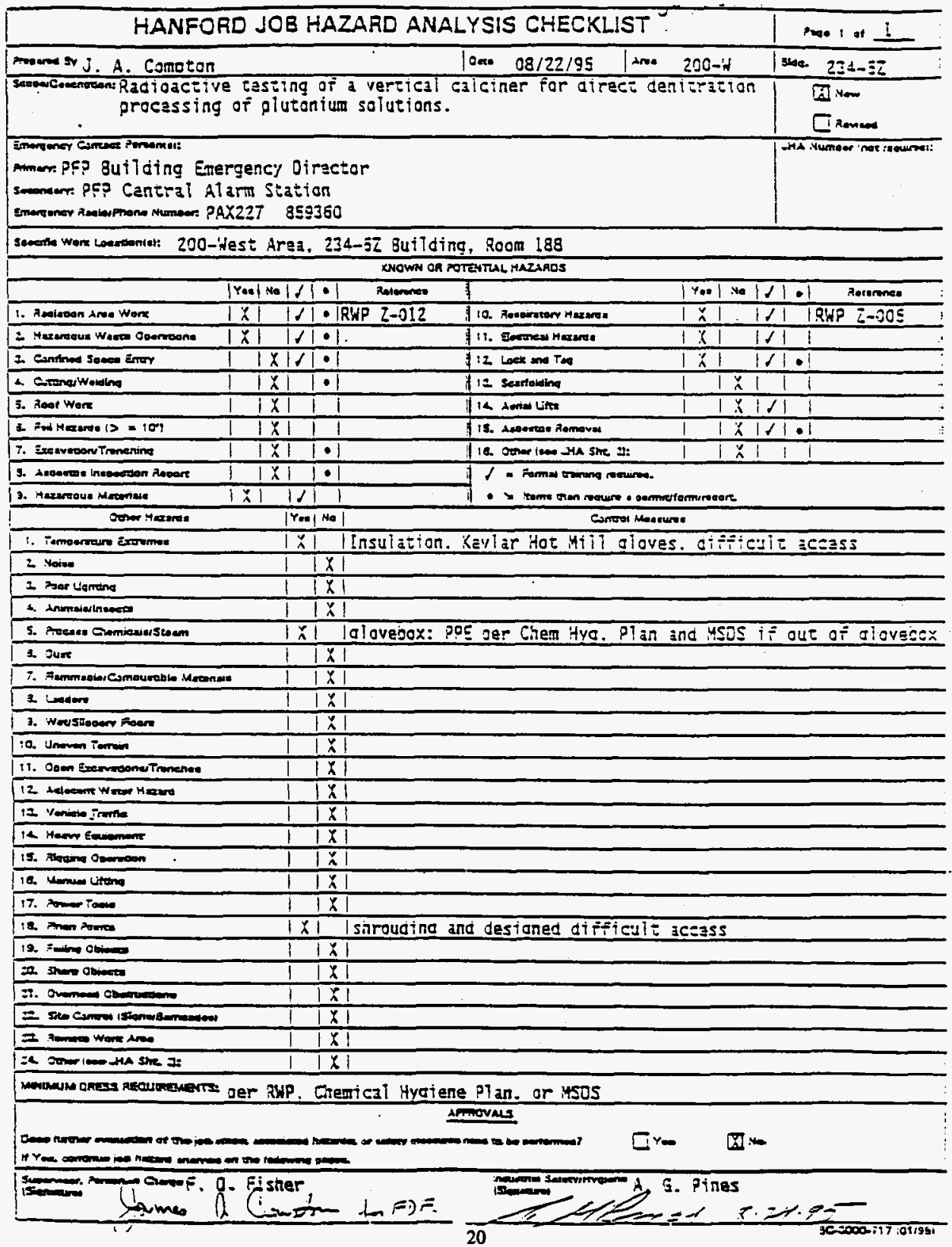




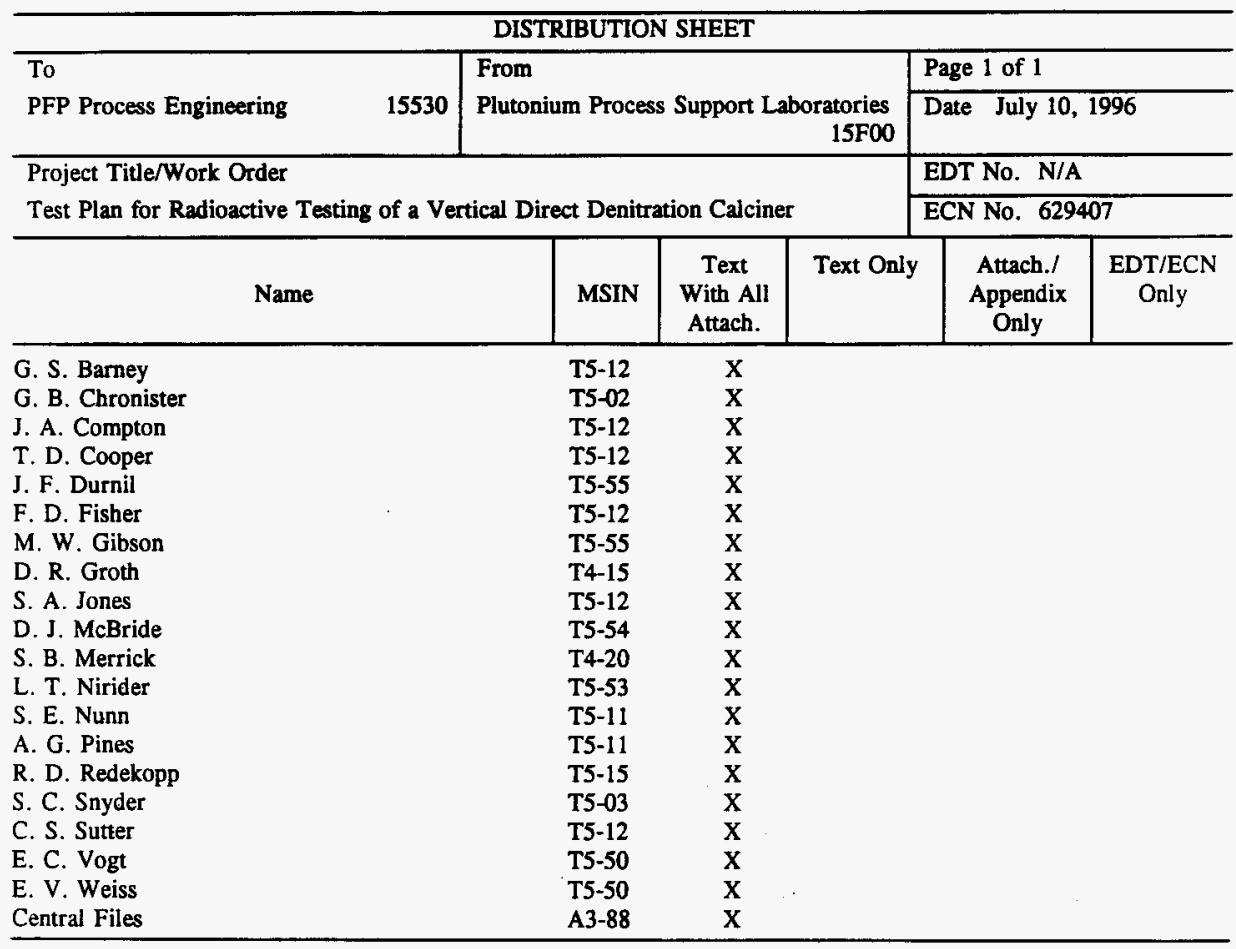


COS:

\begin{tabular}{|c|c|c|}
\hline ENGINEERING CHANGE NOTICE & Pase 1 of 2 & 1. ECN 629407 \\
\hline
\end{tabular}

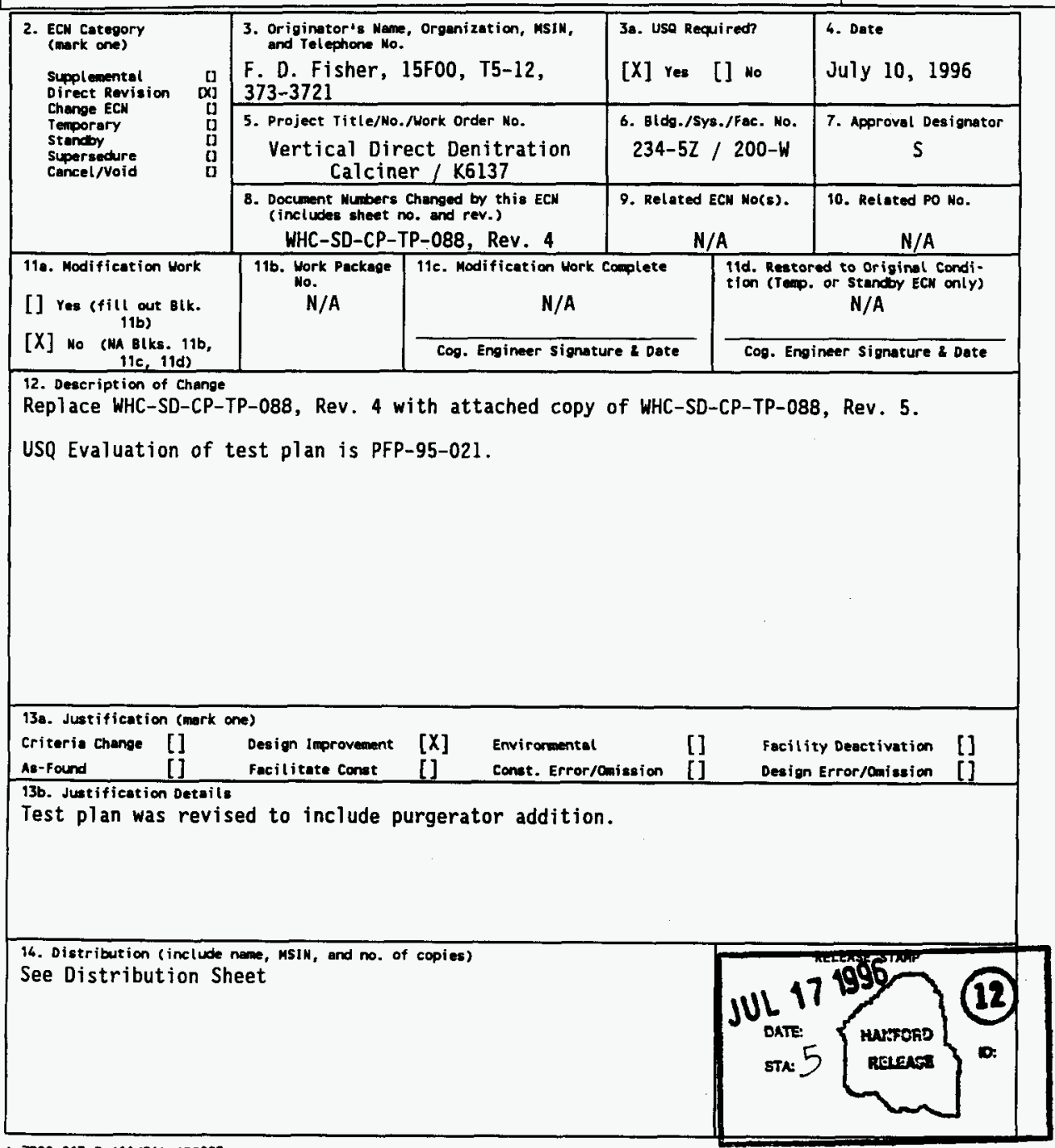

A-7900-013-2 (11/94) GEF095 


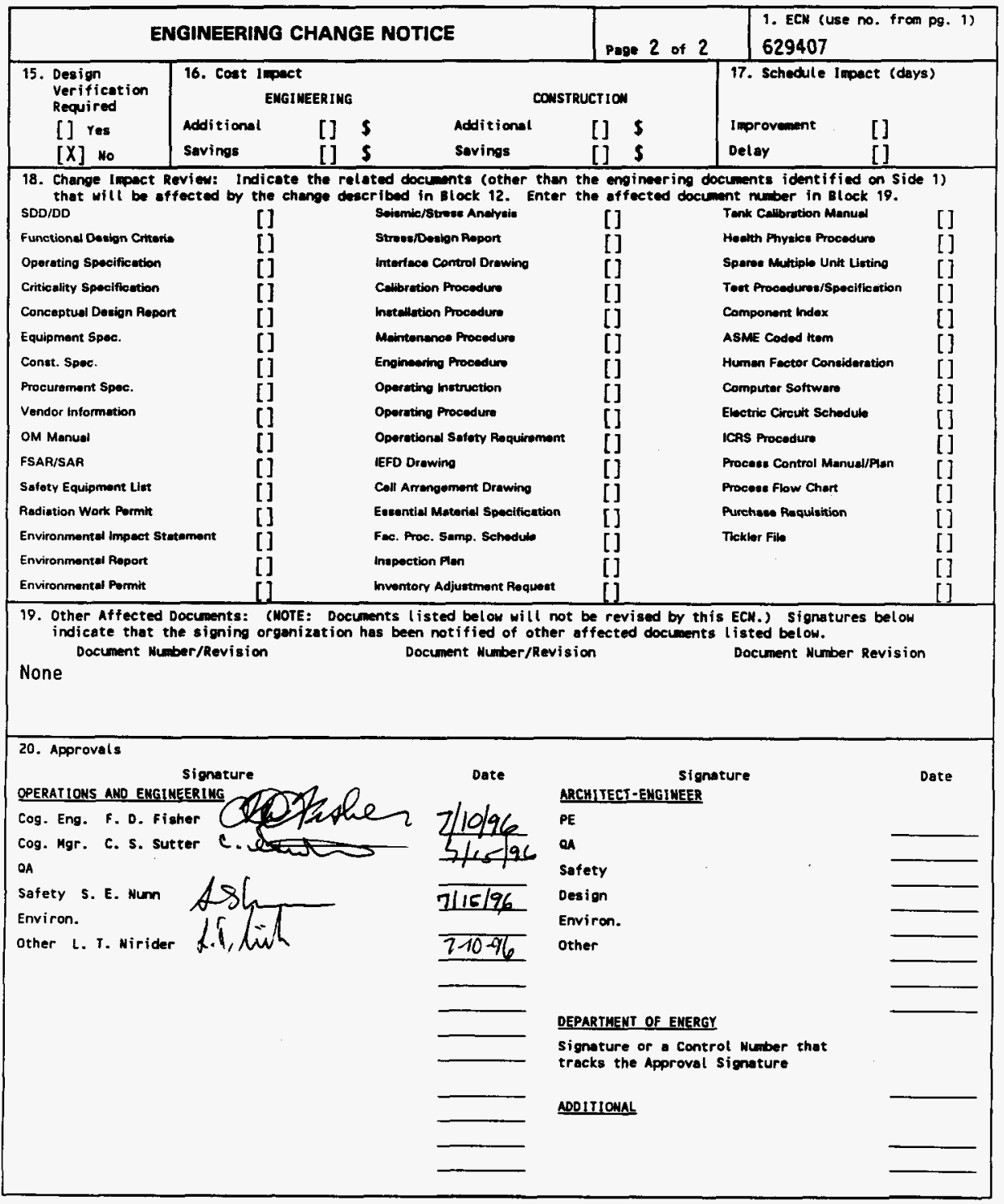




\title{
Test Plan for Radioactive Testing of a Vertical Direct Denitration Calciner
}

\author{
F. D. Fisher
}

Westinghouse Hanford Company, Richland, WA 99352

U.S. Department of Energy Contract DE-AC06-87RL10930

$\begin{array}{lll}\text { EDT/ECN: } & 629407 & \text { UC: } 2050 \\ \text { Org Code: } & 15 F 00 & \text { Charge Code: K6137 } \\ \text { B\&R Code: } & \text { EW7003000 } & \text { Total Pages: } 20020\end{array}$

Key Words: Test Plan, Direct Denitration, Vertical Calciner, Pu-Bearing Liquors

Abstract: A vertical calciner will be used to demonstrate the direct denitration process for converting plutonium-bearing liquors to stable plutonium rich solids. The calciner and some of its associated equipment were previously tested with non-radioactive chemicals to demonstrate operability.

TRADEMARK DISCLAIMER. Reference herein to any specific commercial product, process, or service by trade name, tradewark, manufacturer, or otherwise, does not necessarily constitute or imply its endorsement, recomendation, or favoring by the United states Goverment or any agency thereof or its contractors or subeontractors.

Printed in the United states of Merica. To obtoin copies of this document, contact: WHC/BCS Docunent Contral Services, P.O. Box 1970, Mailstop H6-08, Richtand WA 99352, Phone (509) 372-2420; Fax (509) 376-4989.
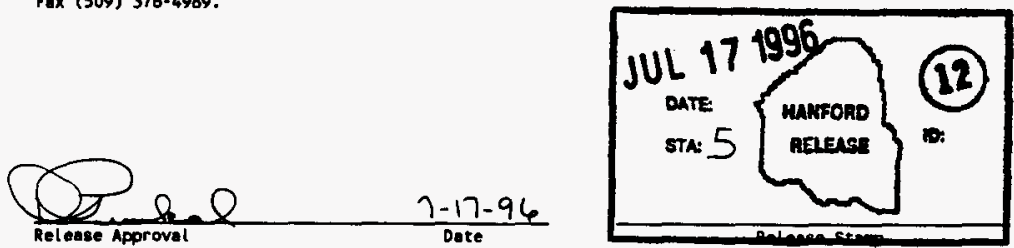

Approved for Public Release 


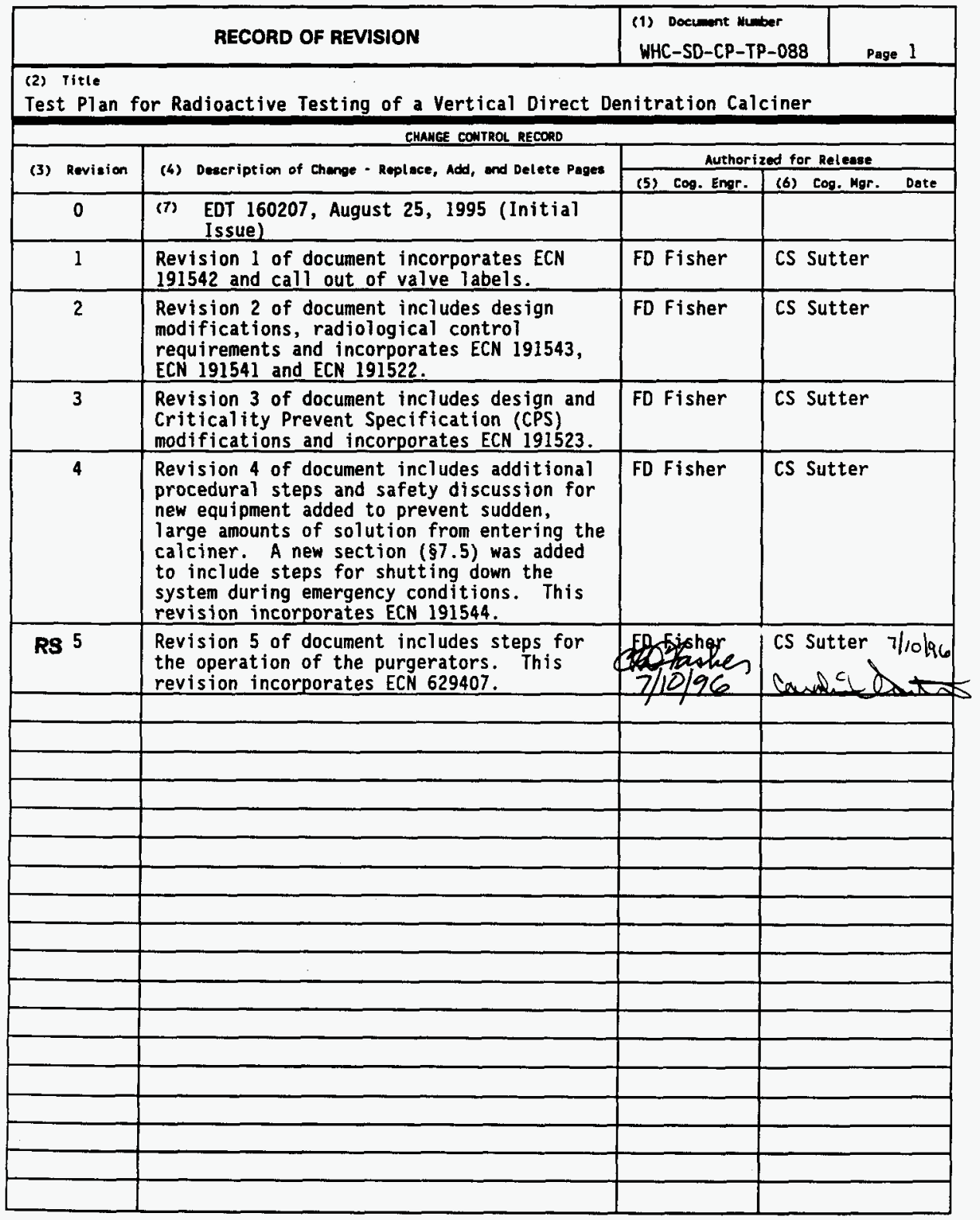




\section{TEST PLAN FOR RADIOACTIVE TESTING OF A VERTICAL DIRECT DENITRATION CALCINER}

\subsection{INTRODUCTION}

Plutonium-bearing liquors containing plutonium and nitric acid and, possibly, uranium and thorium and hydrochloric, sulfuric, phosphoric and hydrofluoric acids and minor amounts of other substances will be used for development and demonstration of a vertical calciner direct denitration process for conversion of those to stable, storable $\mathrm{PuO}_{2}$-rich solids. Some of those liquors are quite dilute and very impure and may first be subjected to various processes for beneficiation and concentration before direct denitration conversion to $\mathrm{PuO}_{2}$-rich solids suitable for long-term vault storage. Untreated scrap liquors containing some amounts of chioride and, possibly, fluoride, sulfate, phosphate, sodium and/or potassium may also be tested for suitability of direct denitration for conversion directly to $\mathrm{PuO}_{2}$-rich solids.

In the vertical calciner direct denitration process to be examined, small additions of liquid feed are metered into a continuously heated and stirred bed of previously generated product solids. The liquid feed is rapidly evaporated, then, more slowly, undergoes drying and denitration and final heat treatment to stable $\mathrm{PuO}_{2}$. The $\mathrm{PuO}_{2}$ product may contain some residual sulfate and/or phosphatederived impurities, but will be substantially free of chloride, fluoride, and other volatile acid impurities. Off-gas condensates are expected to be non-TRU. The process is known to work with plutonium, thorium, uranium, and mixtures of those elements in concentrations ranging from 15 to $500 \mathrm{~g} / \mathrm{L}$. That range may be extended down to ca. $5 \mathrm{~g} / \mathrm{L}$. Schematic diagrams of the vertical calciner and a typical direct denitration flowsheet are Figures 1 and 2.

Problems include materials of construction resistant to abrasion and to $\mathrm{HCl}$ and $\mathrm{HF}$ at $500^{\circ}-1000^{\circ} \mathrm{C}$. Since there is no continuous liquid phase, corrosion is limited to vapor phase attack. Ordinary stainless steel may be adequate for the short term although it would exhibit some oxide scaling on the hotter portions of the calciner. A somewhat higher alloy will be more resistant to oxide scaling. The abrasion problem is not extremely severe and since shaft seals submerged in the powder bed are avoided by design, austenitic alloy construction will be adequate. Hard facing of impellers is not believed to be necessary. Suitable bearings for the impeller shaft present formidable materials problems: graphite is in place now and is expected to wear and, in the case of the lower bearing, to experience some oxidation. Frequent inspection and occasional replacement may be required.

The process is not particularly energy efficient for very dilute feeds and cannot handle feeds high in sodium and potassium or other constituents that form nitrates that are molten and refractory at $\leq 1000^{\circ} \mathrm{C}$ such as acid solutions which have been neutralized with $\mathrm{NaOH}$ or $\mathrm{KOH}$. Organic impurities are largely consumed and only partly report to the offgas.

A vertical calciner has been built and will be used along with associated ancillary equipment in Glovebox 188-1 to demonstrate direct denitration processing of various plutonium solutions to stable, storable $\mathrm{PuO}_{2}$-rich solids. Prior to that, it was temporarily installed in Hood 202-1 and operated "cold," i.e., with non-radioactive stand-in materials, to demonstrate adequate performance of the calciner and most of its associated ancillary equipment items and systems. 
WHC-SD-CP-TP-088 Rev. 5

Figure 1. Schematic Diagram of Vertical Calciner

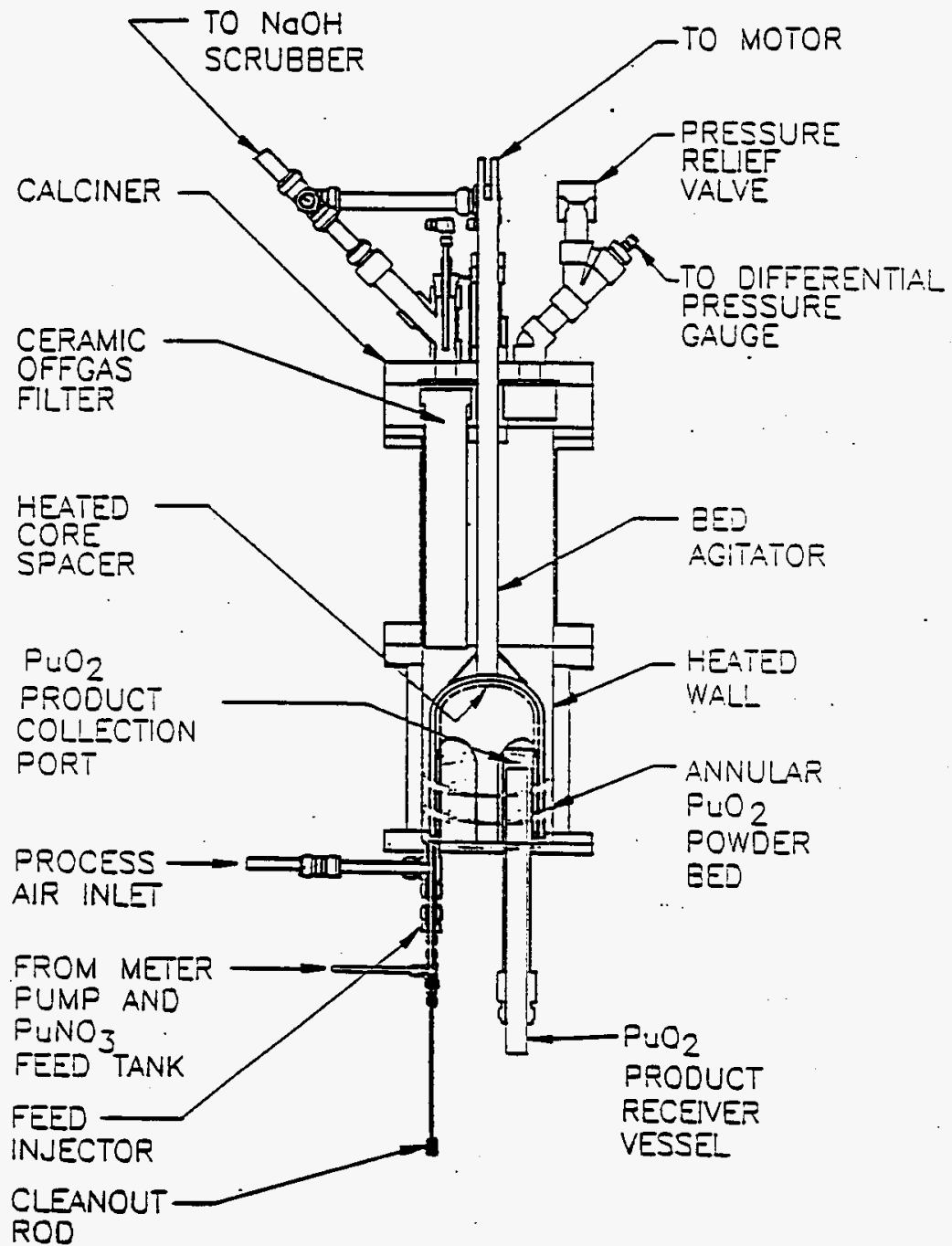


Figure 2. Typical Direct Denitration Flowsheet

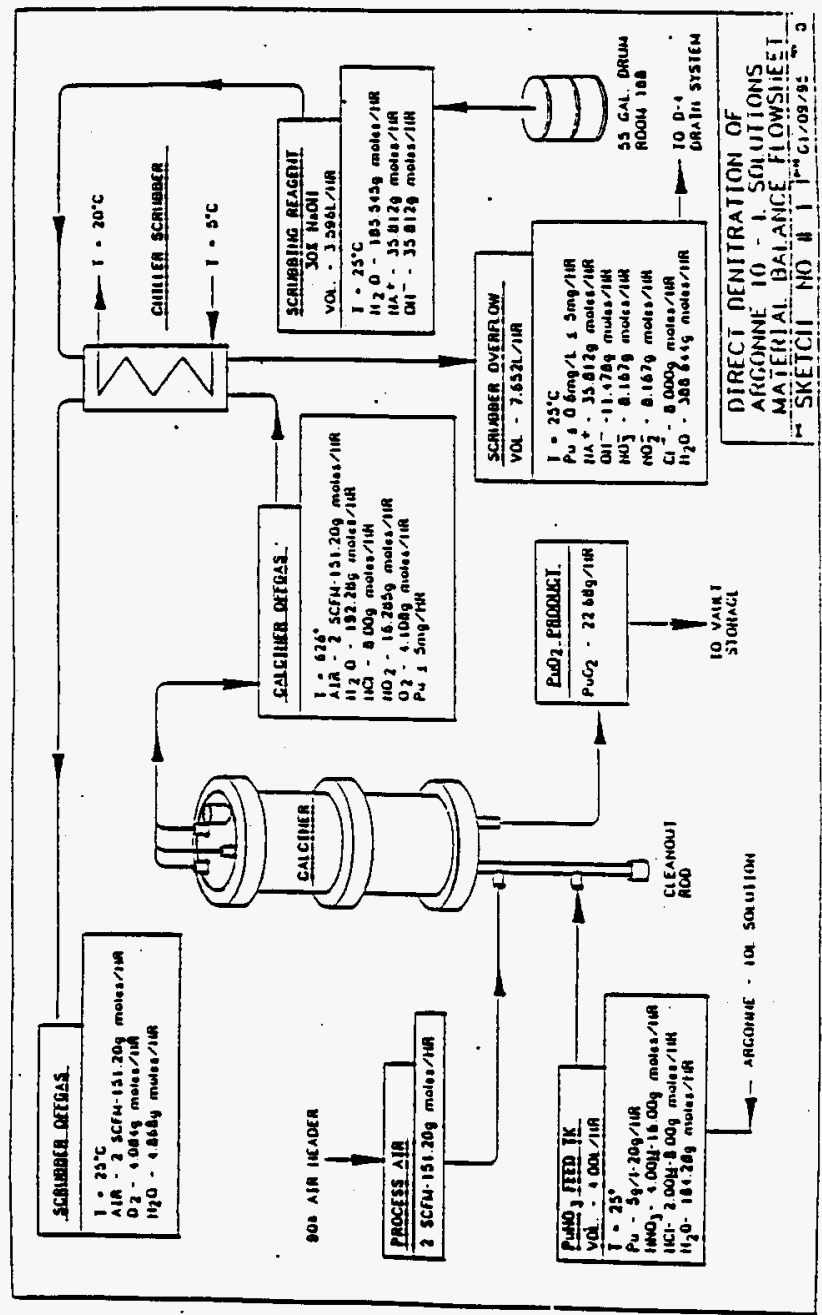




\subsection{OBJECTIVE}

1. To demonstrate satisfactory direct denitration conversion of plutonium bearing solutions to stable solids in a vertical calciner and ancillaries system.

2. To demonstrate the adequacy of performance of the crucial components of a vertical calciner and ancillaries system for direct denitration processing of Pu bearing solutions and to determine deficiencies for possible remediation.

\subsection{SCOPE}

A production-scale vertical calciner and its ancillary equipment will be operated by the Plutonium Process Support Laboratories for several hundred hours with Pu bearing solutions in Glovebox 188-1. The primary source of calciner feed was to have been dilute Pu scrap solutions from ANL but those have been processed by other means. About $400 \mathrm{~g}$ Pu of those purified by anion exchange or EIChrom were converted to $\mathrm{PuO}_{2}$ in the vertical calciner. Further testing will be with other plant solutions.

\subsection{DESCRIPTION OF TEST}

\subsection{Test Items}

The primary test item is the vertical calciner, which is built from high chromium, high nickel Type $310 S$ stainless steel and field insulated. The calciner has an annular design with a 6 inch sch.10 pipe outer shell and an inner shell of 4 inch pipe. The top of the inner shell is a dome shaped pipe cap. Solids inside the calciner are mixed and moved by a 4-tine agitator that fits inside the annulus, covers the dome, and extends out the top center of the apparatus. A chain drive connects the top of the agitator shaft to an offset drive motor. The calciner outer chamber extends above the dome and contains 3 blow back filter elements and a pressure relief device. The agitator shaft is supported in the top plates by two graphite or other bushings and a stuffing box gland. See Figure 1 .

Crucial supporting equipment used with the calciner includes an offgas scrubber chiller, feed tank and metering pump, scrub solution tank and metering pump, phase separators, and a vacuum trap. All these items and the calciner are installed in Glovebox 188-1. The scrubber chiller is kept at a constant temperature by a recirculating water chiller located outside the glovebox. See Figure 2. The calciner control panel is also located outside the glovebox.

Also used will be mounting supports; wiring and instrument lines; interconnecting piping and service lines; and vacuum and compressed air utilities. Electrical services will be via a load center tapped into existing 480-volt service.

Drawing numbers for the crucial equipment pieces and installation are given in Table 1.

The test items also include an about 4 inch deep starter bed of plutonium dioxide in the vertical calciner and a feed stream of plutonium nitrate in nitric acid solution. Additional chemicals may also be present in the feed, notably hydrochloric acid. Plutonium nitrate solution undergoes evaporation and thermal decomposition in the heated stirred bed vertical calciner largely according to: 
TABLE 1

PRIMARY EQUIPMENT DRAWINGS

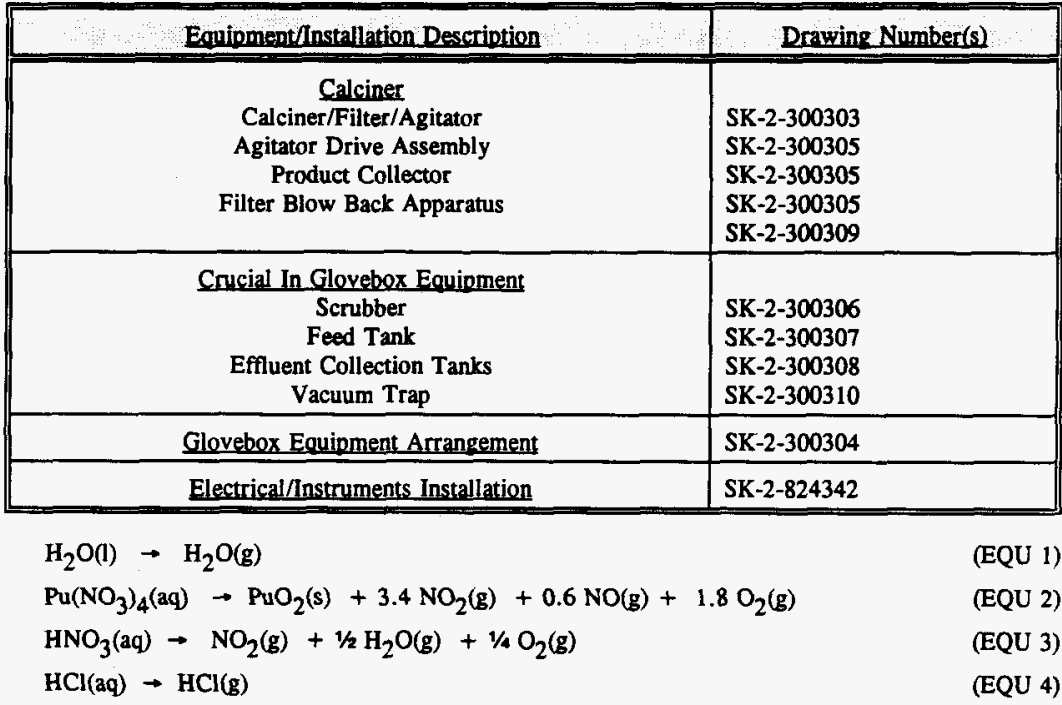

The solid plutonium dioxide formed increases the bed volume, causing solids to overflow to a product receiver vessel below the calciner.

The chiller-scrubber will be used during this test program with recirculating chilled water. The inlet temperature will be about $5^{\circ} \mathrm{C}$ and the outlet temperature is predicted to be about $20^{\circ} \mathrm{C}$. The scrubber will be operated with continuous $30 \%$ sodium hydroxide solution introduction and constant overflow of spent scrub liquor. During the cold testing with tap water as both scrub liquor and cooling water, acid vapors, although less than expected in the hot testing, and their sensible and latent heats were completely removed from the heated offgases.

Other items to be tested include the vacuum regulator, three six point thermocouple recorders, both calciner heaters and their power supplies and controllers.

\subsection{Test Environment}

The testing will be performed in Glovebox 188-1 in Room 188 of the 234-5Z Building, 200-West Area. Control and measurement equipment will be arranged around that glovebox, as appropriate. The glovebox provides confinement of the chemicals in use. The glovebox will breathe room air through three 8 " $\times 8$ " $\times 4$ " inlet filters and will exhaust through three like filters to the E-4 system. 


\subsection{Equipment and Facilities}

Equipment, other than that being tested, includes normal glovebox supporting equipment, an electronic balance, canning supplies and machines, and 4 liter or smaller bottles of plutonium nitrate solution for feed.

Other facilities to be used include Room 190 for vault storage of product and the building radioactive drain system for spent scrubber-chiller liquors.

\subsection{Data}

Temperatures to be measured and recorded include:

$\diamond \quad$ Calciner exterior wall (2 locations, 1 for control and 1 for high temperature alarm)

$\checkmark \quad$ Calciner dome

$\checkmark \quad$ Calciner base plate

$\checkmark \quad$ Filter chamber exterior ( 2 locations)

- Tubing exterior of filtered exhaust ( 2 locations)

Glovebox interior (at E-4 filters)

$\checkmark \quad$ Scrubbed exhaust gases

$\diamond \quad$ Scrubber cooling water inlet and outlet

$\diamond \quad$ Drive motor exterior

Pressures to be periodically measured and recorded are the pressure difference across the blowback filter elements and the vacuum level inside the calciner filter chamber. All pressure recording will be manual.

The only flow rate measured directly is the pressurized air flow into the calciner at the feed port via a rotameter. Times and solution levels inside the feed tank will be used to check the metered feed flow rate. Scrub solution metered flow rates may be checked in the same manner.

Feed volumes and plutonium concentrations will be known before entry into the glovebox. Product weights will be obtained via the electronic balance inside the glovebox. Product plutonium contents will be determined by calorimetric measurements in 2736-ZB. They will be estimated for transfer purposes prior to those. Records of these amounts will be kept in the laboratory notebook.

\subsection{Criteria/Constraints}

These tests do not require revision to the PFP Facility Safety Analysis Repor (FSAR) (Ref. 1). An Unreviewed Safety Question evaluation, number PFP-95-21, of the test plan for radioactive testing of a vertical direct denitration calciner confirmed that the test operations are within the scope of the FSAR.

\subsection{EXPECTED RESULTS}

The calciner and its associated ancillaries are expected to function smoothly and adequately and that the design throughput capability of $4 \mathrm{~L} / \mathrm{hr}$ of feed solution will be achieved. The calciner and ancillaries are expected to withstand corrosive attack by the acid mixtures in the feeds through the life of the tests. Products from this calciner are expected to exhibit a Loss on Ignition (LOI) of $<0.5$ weight percent at $950^{\circ} \mathrm{C}$. These results are expected with moderately impure solutions and with 
relatively pure feeds prepared from impure solutions by anion exchange and with PUREX or PRF product solutions.

\subsection{SAFETY}

\subsection{Criticality}

Criticality Safety Evaluation Report (CSER) 95-005 and Criticality Prevention Specification (CPS) CPS-L-114-00050 were written exclusively for these tests. This CPS allows any quantity of plutonium at a density not to exceed $5.5 \mathrm{~g} \mathrm{Pu} / \mathrm{cm}^{3}$ in the calciner in Glovebox 188-1 but with severe restrictions on water and aqueous solution availability. Strict adherence to this CPS and related postings will be maintained. Monthly internal inspections by PPSL personnel and additional inspections by the PFP Criticality Safety Representative (CSR) serve as additional compliance checks.

The equipment arrangement design was studied and approved by the CSR prior to issuance.

Densities of delivered $\mathrm{PuO}_{2}$-rich products and, thus, the density of the material in the stirred bed of the calciner will be periodically measured, recorded, and trended to allow operation to cease before, if ever, densities exceed $5.5 \mathrm{~g} \mathrm{Pu} / \mathrm{cm}^{3}$.

The cooling water system for the scrubber presents another theoretical criticality prevention problem. The loop contains about 20 liters of water, much of which is in a reservoir inside the chiller. The reservoir geometry is not favorable for criticality prevention. A criticality is extremely unlikely in the reservoir for four reasons. First, there would have to be simultaneous leaks in the cooling water coils inside the scrubber and at least one blow back filter element to allow plutonium into the cooling water. Second, the cooling water is pressurized and the scrubber shell is under vacuum; therefore, the cooling water would flow into the contaminated scrub solution until the cooling water loop is nearly empty. Third, the workers would have to fail to notice the darkening green color of the scrub solution as the plutonium concentration increased to levels that would cause concern for criticality in the reservoir. The scrubber operates with a constant overflow to the "geometrically favorable" effluent disengagers; therefore, some plutonium would exit the scrubber to those tanks, limiting the plutonium available to enter the cooling loop. Finally, the workers would have to fail to notice the malfunction in the chiller as water is pumped out of the cooling coil into the scrub solution.

\subsection{Radiological Safety}

All work associated with this project will be performed in accordance with the applicable Radiation Work Permits (RWPs). In addition, the dose rates on the glovebox are measured and posted on the glovebox routinely by Radiological Control Technicians (RCTs). The RCTs also routinely check air samplers and Continuous Air Monitors (CAMs) for proper operation and satisfactory work conditions. An RCT must also be present whenever items are moved into or out of the glovebox.

The recirculating cooling water between the chiller and the scrubber-chiller could leak from the tubing. The volume of water in the closed cooling loop is finite and fairly small. The cooling water is theoretically sealed from contamination sources; however, leaks from the contaminated scrub solution into the cooling water are possible. The scrub solution should not be extensively contaminated, though, unless at least one blow back filter element also is breached. Consequently, any leaks should be not only small in volume, but also low in contamination. Additionally, the chiller, scrubber, and connecting tubing are all completely within posted Contamination Areas. 
Work involving the use of pressurized air inside a glovebox presents the theoretical possibility of pressurizing the glovebox. Glovebox 188-1 was analyzed for potential pressurization previously with air supplied to the glovebox at 15 psig (Ref. 6); pressurization was determined not to be possible. Additional calculations have since been made for air at $40 \mathrm{psig}$ with the same conclusion. At $40 \mathrm{psig}$, the single air pipe entering the glovebox could deliver only $29.8 \mathrm{scfm}$ and that flow rate of air would be exhausted at a glovebox pressure of only 0.21 inch of water with the glovebox exhaust sealed completely. If both pressure regulators in the air supply line failed simultaneously and made 90 psig air available, the maximum pressure inside the glovebox would still be under 2 inches of water, which is well within the normal operating range for the glovebox inlet HEPA filters. Since these analyses were performed, the inlet air filters have been tripled, thus, further reducing the potential for glovebox pressurization.

Air is introduced into an external mix two-fluid nozzle in the base plate of the vertical calciner. The second fluid is plutonium nitrate solutions. In normal operation the plutonium nitrate solutions are pumped into a central channel in the nozzle assembly and the air enters a concentric outer channel and exhausts at the central channel opening through annular slits. The high velocity air atomizes the exiting plutonium nitrate solution and mixes the aerosolized plutonium nitrate with hot $\mathrm{PuO}_{2}$ powder in the bed above the nozzle where the plutonium nitrate droplets are evaporated, dried, and calcined to $\mathrm{PuO}_{2}$. It is unlikely that nozzle could crust over with dried solid accretions and result in plutonium nitrate solutions being injected into the air channel by the up to 55 psig pressure of the plutonium nitrate feed pump overriding the $65 \mathrm{psig}$ normal atomizing air pressure, or none at all if the compressor should fail. The nozzle is in the calciner bottom plate and is closely wiped by the impeller tines such that an accretion over the nozzle is completely wiped off or made very thin and fractured four times a second by the rotating tines of the vertical impeller. If the impeller is off, so is the feed pump. Nonetheless, a pressure switch in the glovebox air supply header will turn off the feed pump if the air pressure drops below about $60 \mathrm{psig}$, thus actively precluding gross amounts of plutonium bearing liquids being injected into the compressed air supply header. In addition, a bubble-tight check valve is installed in the air line near the feed nozzle.

\subsection{Industrial Safety}

This testing involves high-temperature, electrically heated chemical processing equipment. The thermally hot equipment is extensively insulated and warm surfaces are difficult to reach. The highest exterior temperature recorded during non-radioactive operation was $92^{\circ} \mathrm{C}$ on the agitator shaft where it extends out from the calciner, which is an extremely difficult location to reach inside the glovebox. Temperature-resistant $\operatorname{Kevlar}^{1}$ Hot Mill gloves rated at $450^{\circ} \mathrm{F}$ are available and will be worn if reaching near the warm surfaces is required. Maintenance work will be performed after the calciner has had ample time to cool, if at all possible.

The calciner and scrubber are tall, heavy pieces of equipment and require supports to maintain their upright orientation. The needed supports are provided and are adequate to prevent the equipment from tipping. A hoist is provided in the glovebox to assist with maintenance activities, when needed.

The only exposed rotating part is the top of the agitator shaft, which is difficult and unnecessary to reach during normal operation. The exposed portion contains no sharp or protruding edges. Other pieces of moving or rotating equipment, most notably the agitator drive system, are shielded from workers by guards and/or are difficult to reach during normal operation. The provisions of the WHC

\footnotetext{
${ }^{1}$ Kevlar is a registered trademark of E. I. duPont de Nemours and Co., Inc., Wilmington, DE.
} 
Industrial Safety Manual will be used to maintain safety during maintenance involving rotating or moving parts. A Job Hazards Analysis is attached to this Test Plan (See Attachment 1).

\subsection{Electrical Safety}

All equipment is installed according to designs approved by the appropriate safety organizations. Electrical connections are tested for proper installation prior to starting these tests. Bare electrical connections will not be accessible to casual contact. The provisions of the WHC Industrial Safety Manual will be used to maintain safety during maintenance involving electrical parts. A Job Hazards Analysis is attached to this Test Plan (See Attachment 1).

\subsection{Chemical Safety}

Most chemical operations occur inside the glovebox, which shields workers from chemical hazards. Protective clothing required by the RWPs and the glovebox ventilation system serve as additional barriers to chemical exposure. Chemical safety outside the glovebox is assured by rigid adherence to the PPSL Chemical Hygiene Plan (Ref. 7). The MSDSs for all non-radioactive chemicals are available in Corridor 8.

Due to the high operating temperature reached prior to feed commencement, any sudden "large" amounts of feed entering the calciner will vaporize rapidly, possibly overwhelming the off-gas system's ability to remove the vapors as they form. The introduction of a large amount of feed suddenly is most likely to occur when clearing a solid plug in the feed nozzle if the plug is not noticed quickly. This possibility is minimized by the installation of a check valve before the pressurized air enters the annulus around the solution feed line. In addition, a rotameter in the pressurized air line just before the check valve allows easier detection of pluggage. A cessation of flow through the rotameter indicates that the feed nozzle may be plugged. Also, any detection of solution flowing backward through the rotameter indicates that the check valve is not working and solution is accumulating in the pressurized air system. The pressurized air might drive the accumulated solution volume into the calciner very suddenly once the plug is cleared; therefore, steps are included in the Procedure section to minimize this possibility. First, plug removal requires that the feed pump be shut off and that the pressurized air system be shut off and vented. This step eliminates the motive force for driving solution into the calciner. Second, if any significant accumulation of feed solution is suspected in the pressurized air system, the calciner must be shut down and the feed and/or air lines disassembled to remove the accumulated solution.

Overpressurization of the calciner from chemical reactions or excessive feed flow is minimized by a pressure relief device. The device is a 3/4-inch hole at the top of the calciner with a cap held on by gravity and beveled edges. The cap will be lifted upward to relieve pressure starting at 1.3 psig. Experience during non-radioactive testing has confirmed that the pressure relief device works as intended.

That relief valve can vent all the gases generated in or introduced into the calciner at any realistic rate at well below the pressure required to rupture the calciner, i.e., about $300 \mathrm{psig}$, even with the offgas system sealed off. The feed pump will not inject feed at pressures above 55 psig. The atomizing air and blowback air are normally 60-65 psig, but the ultimate pressure available to both of those is only 90 psig. A steam surge from siphoning back of scrub liquor into a hot calciner would be limited by pressurization terminating the siphoning after only a small amount of scrub liquor was introduced to the hot calciner and the pressure would be safely vented back to the scrubber-chiller and through the relief valve. 
Four methods are used to prevent organics from entering the calciner, where they might combust. First, the download procedure for removing the solutions from their original containers requires a visual check for a second liquid phase. Second, sample analyses by the PFP Analytical Laboratory confirm the lack of organies in the feed samples. Third, most of the calciner feed solution has been processed through either an anion exchange column or an extraction chromatography column, which would separate organics from the plutonium. Finally, the feed tank in the calciner glovebox is glass, allowing staff to notice any organic phase in the feed. The calciner can safely accept small to moderate amounts of organics. Those are promptly combusted upon introduction and, thus, cannot accumulate into hazardous quantities.

\subsection{TEST PROCEDURE}

\subsection{Operability Check}

\section{NOTE}

This section may be interrupted, as needed, to obtain craft support for repairs, adjustments, or corrections to equipment and instaltation. Rigorous compliance with the PFP Lock and Tag program is required for all maintenance activities.

1. Turn on power to the control panel. Ensure that all lights, controls, and recorders have power and are operating properly for this stage of operation.

2. Program the temperature controllers and recorders, as needed, if not still programmed correctly from prior operations. Programming instructions are in the operating manual (Ref. 2 and 3 ).

3. Open the valve for the building vacuum system and adjust regulator to 44 inches $\mathrm{H}_{2} \mathrm{O}$ or other as directed in laboratory notebook in the calciner. Close vacuum system valve after adjustments are made.

4. Add the starter bed of $\mathrm{PuO}_{2}$ to the calciner, as follows:

a. Start the calciner agitator. Building vacuum may also be used, if available. Product receiver must be in place.

b. Remove the top half of the pressure relief device to uncover the vent hole.

c. Insert a funnel into the pressure relief hole.

d. Carefully pour the $\mathrm{PuO}_{2}$ from its container(s) into the calciner through the funnel. Tap or shake the funnel gently to assist the powder in flowing down into the calciner chamber. Use a brush or scoopula, if needed, to assist in removing the powder from the original container(s).

e. When finished loading, brush or shake as much powder as possibie from the funnel into the calciner.

f. Remove the funnel and place the top half of the pressure relief device back in position.

g. Turn off the agitator and the vacuum.

5. Add ca. $0.5 \mathrm{~L}$ water to the feed tank. Temporarily connect feed pump to utility outlet. Prime the feed pump per the operating manual's instructions (Ref. 4) with the pump outlet line disconnected from the calciner. Shut off the pump when the first drop of liquid exits the outlet line. Reconnect the feed line to the calciner. Reconnect the feed pump to the panel controlled power supply. 
NOTE

The pump stroke frequency may be changed at any time, but the pump stroke length may be changed only when the pump is running.

6. Temporarily connect the $30 \% \mathrm{NaOH}$ scrubber-chiller feed pump to the utility outlet and a water supply.

7. Prime the $30 \% \mathrm{NaOH}$ scrubber-chiller-feed pump with water per the operating manual's instructions at $100 \%$ flow and fill the scrubber-chiller about $2 / 3$ full of water. Visually check lines and joints for leaks. Insert foot valve into $\mathrm{NaOH}$ drum. Reconnect pump to panel controlled power supply.

8. Fill the closed cooling loop between the chiller and scrubber with water. Turn on the chiller per the operating manual's instructions (Ref. 5) to begin circulating the cooling water and confirm that the chiller is operating properly. Visually check lines and joints for leaks. Shut off the chiller after confirming acceptable operation.

9. Turn on the agitator drive motor and adjust the rotational speed, as desired. Nominally 60 RPM. Record the rotational speed and necessary dial setting in the laboratory notebook for later reference. Additional speeds and their dial settings may also be determined and recorded, if desired. Turn off the agitator drive system.

10. Open the valve for the compressed air supply and adjust the regulators, if necessary, for the desired line pressure, i.e., 65 psig to glovebox and blow-back system and 65 psig to atomizing nozzle. Close the compressed air valve after adjustment is made.

11. Turn on the blow-back timing system and adjust, as needed. Nominally 0.5 second pulses every 90 seconds. Turn system off after adjustments are made.

12. Confirm that the calciner heater controller is still programmed properly from prior tests.

Temperature set point is $1000^{\circ} \mathrm{C}$. Ramp up rate is $8^{\circ} \mathrm{C}$ per minute. Ramp down rate is $5^{\circ} \mathrm{C}$ per minute. Overtemp alarm at $1150^{\circ} \mathrm{C}$. Others as directed by logbook direction. Turn on power to the heaters long enough to confirm that (a) the calciner is heating at the proper rate and (b) the increasing temperatures are being recorded on the temperature indicators and recorders. Shut off the controller program by depressing the Up Arrow and Down Arrow simultaneously on the controller face.

13. Shut off power to the control panel, if desired or necessary.

\subsection{Start-Up}

\section{NOTE}

Step 6 may be performed at any time prior to the stated temperature of $400^{\circ} \mathrm{C}$, if necessary due to room access limitations.

1. Introduce plutonium nitrate feed, as required, into the glovebox per ZP-100-002, "Seal In- PPSL Gloveboxes" or ZP-100-003, "Use PPSL Airlocks", and thence, into the feed tank. Enter on inventory posting sheet and into notebook. 
2. Ensure that heat controller and temperature alarm thermocouples are in their proper positions. Turn on power to the calciner heaters. Check programming for control temperature set point to be $1000^{\circ} \mathrm{C}$, ramp up at $8^{\circ} \mathrm{C} / \mathrm{min}$, dwell for 60 minutes, ramp down at $5^{\circ} \mathrm{C} / \mathrm{min}$, overtemp alarm at $1150^{\circ} \mathrm{C}$ or others as directed by logbook instruction. Confirm that the calciner is heating at the appropriate rate.

3. Open the valve for the building vacuum system to establish air flow through the calciner and filters.

4. Open the valve for compressed air flow into the calciner. Adjust the rotameter to indicate 30 scth (this indication should correspond to an actual $40 \mathrm{scth}$ after correction for the estimated pressure inside the rotameter) or other rate as specified by logbook instruction.

5. Open valve in product delivery tube. Set purgerators into the product receiver and the calciner pressure sensing line to 1 SCFH or other as directed.

6. Turn on the agitator drive motor. Adjust its speed to 60 RPM or other as directed by logbook instruction.

7. After the controlling temperature on the calciner outer wall reaches $400^{\circ} \mathrm{C}$, turn on the chiller and begin circulating cooling water through the scrubber.

8. After the controlling thermocouple indicates the desired furnace operating temperature, $1000^{\circ} \mathrm{C}$ or other as directed by logbook instruction, increase the compressed air flow rate at the rotameter to an indicated $45 \mathrm{scth}$ (estimated actual $60 \mathrm{scth}$ ) or other as directed by logbook direction.

9. Turn on the filter blow-back system, 65 psig, 0.5 second pulses every ca. 90 seconds, or other as directed by logbook instruction.

10. Turn on the scrub solution pump and begin pumping $30 \% \mathrm{NaOH}$ solution into the scrubber at a rate to equal in hydroxide equivalents the acid in the feed plus enough extra to make the effluent ca. $1.5 \mathrm{M}$ in excess hydroxide, as directed by logbook instruction from prior makeup calculations.

11. Turn on the feed pump and begin pumping feed solution into the calciner at $4.0 \mathrm{~L} / \mathrm{hr}$ or other as directed by logbook instruction. Observe the atomizing air rotameter to confirm that air is still flowing properly into the calciner and that feed solution is NOT flowing backward through the rotameter.

12. Confirm that the valve between the calciner and product collection pot is open.

\subsection{Steady-State Operation}

1. Periodically check the solids content of the product collector. 
2. When the collector is nearly full, empty the collector as follows:

\section{CRITICALITY}

Be certain there is an open corner in the triangular plate beneath the collection pot before starting this sequence.

a. Tare weigh a slip lid can. Assign a number to this can; record the can number and tare weight in the laboratory notebook.

b. Turn off the feed and scrub liquor metering pumps and the purgerator on the product receiver.

c. Close the valve between the calciner and product collection pot.

d. Carefully undo the clamps holding the collection pot in place, making certain that the pot does not fall.

e. Very carefully pour the collected powder from the collection pot into the tared slip-lid can. Use brushes, if needed, to minimize dusting.

f. Reattach the collection pot and open the valve between it and the calciner. Reset the purgerator flow.

g. Restart both the feed and scrub liquor metering pumps.

h. Tare weigh a $10 \mathrm{ml}$ plastic graduated cylinder. Introduce 5 to $7 \mathrm{mls}$ of product $\mathrm{PuO}_{2}$ into the cylinder. Tap down. Measure and record volume. Weigh and record. Return sample to slip-lid can.

i. Weigh the loaded slip-lid can. Record the gross weight in the laboratory notebook. Calculate the net weight of powder and record this amount in the notebook. [Note: The gross weight and net weight may be the same if the balance has an automatic tare feature].

j. Tare weigh a numbered sample bottle. Remove ten grams of powder from the slip lid can and transfer it into the sample bottle. Reweigh the sample bottle to obtain the sample weight. Attach the sample bottle cap and set the sample aside for later submission to the PFP Analytical Laboratory for Loss on Ignition analysis.

k. Place the lid on the slip-lid can and seal with tape. Set the can in an open corner of the triangular plate beneath the collection pot.

1. Calculate product $\mathrm{PuO}_{2}$ density. Note and record. The density may not exceed $5.5 \mathrm{~g}$ Pu/cm (i.e. $6.24 \mathrm{~g}^{3} \mathrm{~cm}^{3}$ ) tap density. Should the measured tap density exceed 6.24 $\mathrm{g} / \mathrm{cm}^{3}$, stop operation, notify the PFP Criticality Representative. Prepare, get reviews and approvals and implement a recovery plan.

3. Monitor the time remaining in the Dwell portion of the temperature controller program. This indication tells you the number of minutes remaining at steady-state operation. The controller will automatically begin to cool at the programmed ramp-down rate when the Dwell time reaches 0.0 minutes. Depress the Run/Hold button any time during the Dwell step to hold the heaters at steady-state operation for as long as necessary. The Dwell step will resume where it stopped when the Run/Hold button is depressed again.

4. Periodically examine the contents of the scrubber-chiller in the lower annular downcomer and the quiescent chamber beside the gas distributor and/or the scrub liquor effluent receiver tanks for turbidity. Marked turbidity indicates a failed offgas filter. Do not mistake finely dispersed gas bubbles for turbidity. Scrub liquors can be slightly turbid with a grayish material, presumably sodium carbonate. 


\section{CRITICALITY}

The scrubber-chiller and the disengagers are critically safe by geometry for plutonium slurries but ALARA principals make it necessary to limit plutonium contents in liquors going to the waste tanks.

Under no circumstances are gross quantities, i.e., approaching the $400 \mathrm{~g} \mathrm{Pu}$ mass limit of the 241 $Z$ receiver tanks, to be introduced into the $D-4$ drain system.

If marked turbidity is noticed, shut down feed and scrubber-chiller liquor pumps, atomizing air, both purgerators and blowback air, and offgas vacuum immediately. Turn off heater power subsequently. Prepare, get appropriate reviews, and implement formal recovery procedures.

5. Observe the feed tank volumes and times to confirm the feed flow rate.

\section{CRITICALITY}

Be certain to check all aspects of the CPS posting before introducing additional feed solution into the glovebox.

6. Periodically, add more feed solution to the feed tank per ZP-100-002, "Seal In - PPSL Gloveboxes", or ZP-100-003, "Use PPSL Airlocks", as needed. Note volumes and concentrations. Enter onto inventory posting sheet and into laboratory notebook. Project necessary scrub liquor rate in notebook calculation. Change serub liquor rate as appropriate.

\section{CRITICALITY}

Do not drain phase disengager if it exhibits marked turbidity. Shut down feed and scrubberchiller liquor, atomizing air, purgerators and blowback air, and offgas vacuum immediately. Turn off heater power subsequently. Prepare, get appropriate reviews, and implement formal recovery procedures.

7. Periodically check the scrub solution disengagers system liquor levels. Make certain that the vacuum trap is operating acceptably. Adjust valving, as needed, to switch between disengagers during operation. Drain the disengager not in use, as needed, per the following instructions:

a. Open the tank vent valve.

b. Drain a sample of the solution from the "full" disengager into a numbered $22 \mathrm{~mL}$ sample bottle.

c. Close the sample cock.

d. Set the sample bottle aside for later submission to the PFP Analytical Laboratory.

e. After receiving sample results and approval of PFP Engineering and PFP Operations, open the valve to the $D-4$ drain and the tank vent valve. 
f. Close the drain valve.

8. Perform frequent checks of the atomizing air rotameter and the feed pump's bypass loop. Confirm that air is flowing properly into the calciner and that solution is not flowing backward through the rotameter. Loss of air flow, liquid flowing through the bypass loop, or backflow of solution through the rotameter indicates probable feed line pluggage that can be cleared as follows:

\section{SAFETY}

If a significant quantity of feed solution is known or suspected to have accumulated in the pressurized air line(s), shut down and contact Maintenance for disassembly of the feed and/or air lines. The steps below are for use only when the loss of air flow is noticed quickly enough to prevent a large amount of feed from entering the calciner rapidly when the plug is cleared.

a. Turn off the agitator.

b. Shut off the feed pump. Relieve the feed pump pressure and allow any feed in the feed and air lines to blow back into the feed tank by pulling the priming knobs on the feed pump outlet assembly. Close these knobs before the feed line is totally empty.

c. Turn off the air supply to the rotameter. In the top level of the glovebox, relieve the pressure in the accumulator tank.

d. Loosen the gland nut at the base of the feed tube assembly to free the clean-out rod.

e. Push the clean-out rod slowly and carefully upward all the way to remove the suspected pluggage. If the rod will not move all the way up, shut down and contact Maintenance for disassembly to correct the problem.

f. Return the clean-out rod to its original position and tighten the gland nut loosened in step d.

g. Turn the pressurized air supply back on. Confirm that air is flowing properly through the rotameter. If air does not flow through rotameter, shut down and contact Maintenance.

h. Turn on the agitator.

i. Turn on the feed pump. If needed, reprime the pump per the operating manual instructions.

\subsection{Shut-Down}

1. After the desired amount of feed has been processed through the caiciner, turn off the power to the calciner heaters. The power may be shut off by any one of the methods below:

a. Allow the temperature controller to finish its programmed Dwell portion of the operating program and it automatically begins to cool. 
b. Simultaneously depress both the Up Arrow and Down Arrow on the face of the temperature controller.

c. [Least desirable method] Push in the button-shaped switch that controls power to the heater controller or turn off the master power switch.

2. Reduce the compressed air flow rate to an indicated 30 scfh or other flow rate, if so directed by logbook notation. Higher flow rates increase the cooling rate for the calciner, making it more likely to be cooled for maintenance the next day. Lower flow rates (or none) decrease the cooling rate and the conserved heat makes the next day's start-up shorter.

3. Before leaving the calciner unattended, shut off the agitator, scrub solution, compressed air, vacuum, and water chiller. Be sure the compressed air is shut off BEFORE shutting off the vacuum. If desired to leave air flowing through the cooling calciner overnight, the vacuum must also be on if the pressurized air is left on. The master power switch may also be tumed off, if desired. Wait about 20 minutes after shutting off the feed pump to allow the bed to stop decomposing and producing $\mathrm{NO}_{\mathbf{x}}$, then remove the cap on the pressure relief device. If fumes exit the relief port, replace the cap and wait longer before leaving the cap off.

\subsection{Emergency Conditions Responses}

1. Criticality Horn

Shut off power at the button-shaped Emergency Shutdown switch on the control panel, if passing by the panel. Run from the building immediately per normal criticality horn response.

\section{Continuous Air Monitor}

If not wearing respiratory protection, shut off power at the button-shaped Emergency Shutdown switch on the control panel, if passing by the panel. Leave the room and contact the Radiological Control Technicians (RCT).

If wearing respiratory protection, continue operation unless ordered to leave by the RCT.

\section{Evacuation Siren}

Shut off power at the button-shaped Emergency Shutdown switch on the control panel. Shut off any other powered devices by depressing their red lights on the control panel. Shut off the compressed air supply (first) and the vacuum supply (second). Crack open the cap on the pressure relief device at the calciner top. Evacuate the room and building per normal evacuation siren response.

4. Fire Alarm

Shut off power at the button-shaped Emergency Shutdown switch on the control panel. Shut off any other powered devices by depressing their red lights on the control panel. Shut off the compressed air supply (first) and the vacuum supply (second). Crack open the cap on the pressure relief device at the calciner top. Evacuate the room and building per normal fire alarm response. 
5. Take Cover Siren

No response is required. Continue operating normally unless instructed to shut down by management.

6. Orderly Exit of Zone III

Shut down normally per Section 7.4. Notify the building Emergency Director that the shutdown and exit will require about half an hour. If directed to leave sooner, use the response for an evacuation siren but without leaving the building.

7. Fissile Material Movement Bans/Restrictions

Shut off only the feed pump, unless directed by management or the Criticality Safety Representative (CSR) to shut down completely (via Section 7.4). The CSR has determined that running the agitator does not constitute "movement of fissile material."

8. Lock-Downs

No response is required, unless specifically directed by Patrol or management. If directed to leave, respond as per the evacuation siren instructions but without leaving the building.

\subsection{QUALITY ASSURANCE}

These tests are being performed to the requirements for prototype equipment as detailed in Standard Engineering Practices (WHC-CM-6-1), Practice EP-2.4, "Development Control Requirements". There are no requirements for independent witnessing or review of tests nor are there any specific standards to be met. Equipment will not be calibrated to NIST-traceable accuracy.

\subsection{ORGANIZATION AND FUNCTION RESPONSIBILITIES}

\subsection{Plutonium Process Support Laboratories}

The PPSL staff prepares all test plans and procedures, performs all tests, and documents results from testing. The PPSL Cognizant Engineer also reviews and approves all designs and procurement for equipment and its installation. The PPSL technical staff also prepares formal presentations based on the test results.

\subsection{PFP Design Engineering}

Design Engineering prepares all fabrication and installation designs and relevant bills of material. Design Engineering also reviews and approves this test plan. Documentation and presentation of designs is also performed. Design Engineering also observes the tests, as needed.

\subsection{PFP Process Engineering}

Process Engineering reviews and approves this test plan and results documentation. Process Engineering also observes the tests, as needed. 


\subsection{PFP Maintenance}

Maintenance crafts review designs, fabricate and install the equipment for use, and may observe the tests.

\subsection{PFP Operations}

The PFP Operations organization provides all required utilities and services to the glovebox and laboratory area, primarily ventilation, vacuum, lighting, electrical power, pressurized air, and water.

Transition Operations provides trained operators to assist with loading equipment into the glovebox and associated tasks, such as decontamination. Transition Operations management also reviews and approves this test plan. Transition Operations personnel may observe testing, as desired.

Solid Waste Operations assists with the disposal of all effluents and wastes.

\subsection{Safety}

The PFP CSR reviews and approves equipment designs for criticality safety, assists with the CSER, and writes the CPS and associated posting(s). The CSR also reviews and approves the test plan for criticality safety concerns. The CSR inspects the PPSL area periodically to confirm compliance with all applicable CPS postings. The CSR also observes the tests, as desired.

The PFP Nuclear Safety representative reviews and approves this test plan and periodically performs surveillances to ensure compliance with nuclear safety requirements, including criticality safety. The nuclear safety representative also observes the tests, as desired.

The PFP Industrial Safety Representative reviews and approves this test plan and performs periodic surveillances to ensure compliance with industrial safety rules. The industrial safety representative also observes the tests, as desired.

\subsection{Quality Assurance}

Quality Assurance personnel review and approve designs and this test plan. Test observations may be performed, as desired.

\subsection{PFP Environmental Engineering}

PFP Environmental Engineering reviews records of effluent solutions and assists in their disposal. PFP Environmental Engineering also reviews and approves this test plan. Test observance may be performed, as desired.

\subsection{PFP Security}

The PFP Security Representative reviews and approves the material requirements and associated safeguards for special nuclear material (SNM) protection. Test observance may be performed, as desired. 


\subsection{Department of Energy}

Department of Energy personnel or their representatives review the test plan. Test observation may be performed, as desired.

\section{SCHEDULE}

These tests are to begin upon completion of equipment acquisition and installation. Tests are anticipated to continue until all Argonne scrap solutions in the PFP inventory have been tested. Additional solutions may be tested, as needed, during or after testing of the Argonne solutions. The duration of testing will not be predicted due to the uncertainties in the numbers of solutions to be tested and any required maintenance or design changes.

\subsection{REPORTS}

A final test report will be issued after completion of these tests. It will be issued as a supporting document, external publication, or speech/article in accordance with Standard Engineering Practices (WHC-CM-6-1), Practice EP-1.12, "Supporting Document Requirements." Progress of the testing will also be reported weekly in the PPSL Weekly Report.

\subsection{REFERENCES}

1. Plutonium Finishing Plant Facility Safery Analysis Report (WHC-SD-CP-SAR-021, Rev. 0), Westinghouse Hanford Company, Richland, WA, January, 1991.

2. Eurotherm Corporation, Bulletin $8180 \mathrm{P}-8$, Euotherm 818 Controller/Programmer Operating Instructions, Eurotherm Corporation, Reston, VA.

3. ABB Kent-Taylor, Inc., Bulletin PB PR100-94.2, "CommanderTM PR100 Advanced Process Recorder," ABB Kent-Taylor, Inc., Rochester, NY, 1994.

4. LMI Corporation, Liquid Metronics Division, Catalog Section 6.0, "Electronic Metering Pumps: Installation, Maintenance, Troubleshooting," LMI Milton-Roy,Acton, MA, July, 1994.

5. Neslab Instruments, Inc., "CTF-300 Recirculating Chiller, Instruction and Operation Manual," Neslab Instruments, Inc., Newington, NH, September 9, 1994.

6. Compton, J. A., Supporting Document WHC-SD-CP-TA-008, Rev. 0, "Comparison of Deliverable and Exhaustible Pressurized Air Flow Rates in Laboratory Gloveboxes," Westinghouse Hanford Company, Richland, WA, August, 1994.

7. Sant, W. H., WHC-SD-CP-HSP-001, Rev. 3, "Westinghouse Hanford Company Chemical Hygiene Plan," Westinghouse Hanford Company, Richland, WA, May 1995.

\subsection{DATA SHEETS}

Data will be recorded in Controlled Laboratory Notebook, WHC-N-967-1, with recorder traces or any other mechanically produced data stored separately as noted in that notebook. Those data items will be identified on the PPSL RIDS plan as record material. 


\section{EST ABAILAELE COPY}

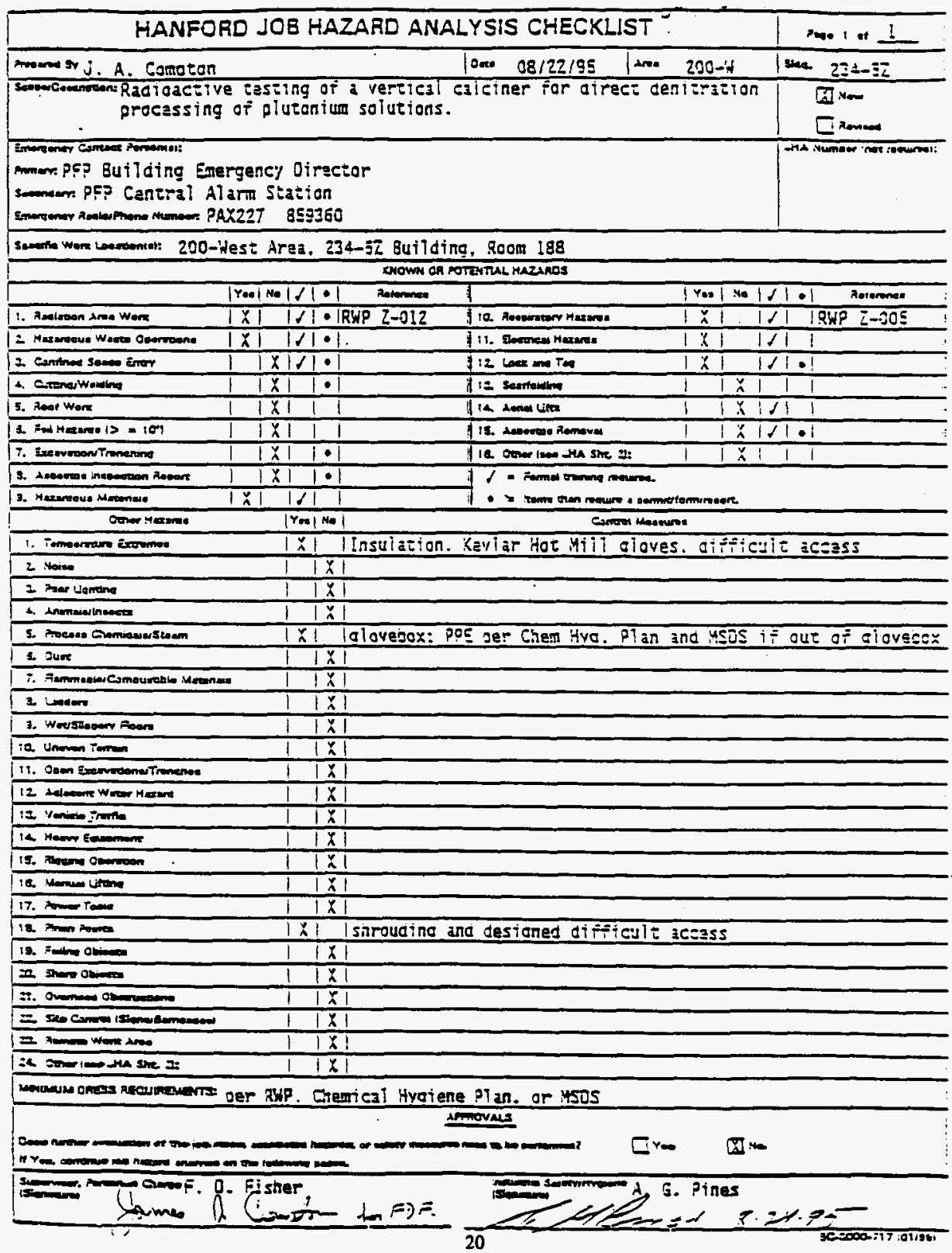




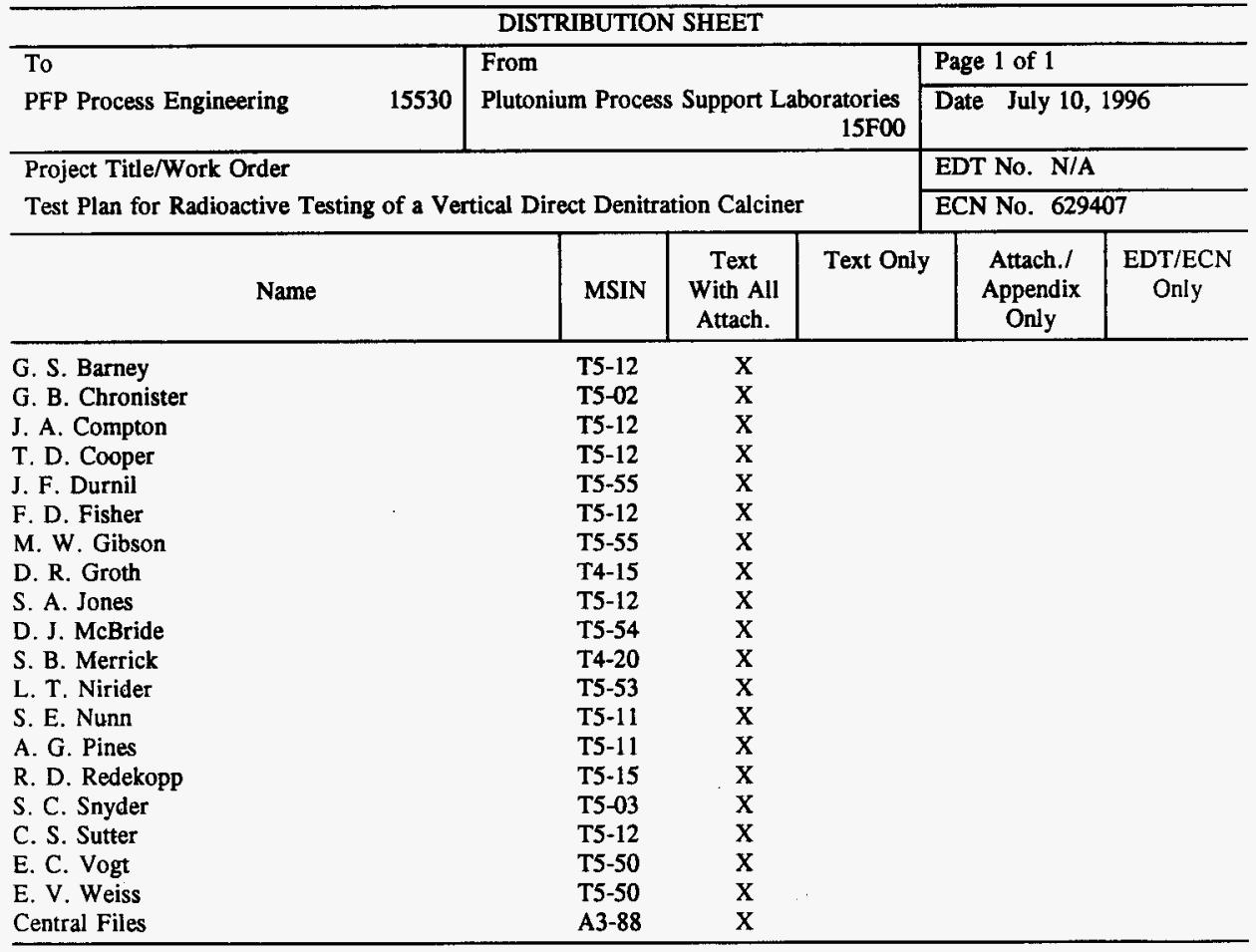

